\title{
Avian Community Density and Distribution Patterns among Nicaraguan Conventional and Organic Shade-Coffee Plantations
}

\author{
Wayne J. Arendt ${ }^{*}$, R. Cary Tuckfield ${ }^{2}$, Juan Carlos Martínez-Sánchez ${ }^{3,4}$, \\ Jennifer L. Reidy5, Frank R. Thompson III', Joseph M. Wunderle Jr.1, \\ José Manuel Zolotoff ${ }^{3}$
}

${ }^{1}$ USDA Forest Service, International Institute of Tropical Forestry, Sabana Field Research Station, Luquillo, PR, USA

${ }^{2}$ ECOSTATys LLC, Aiken, SC, USA

${ }^{3}$ Fundación Cocibolca, Managua, Nicaragua

${ }^{4}$ Department of Biology, University of Washington, Seattle, WA, USA

${ }^{5}$ Department of Fisheries and Wildlife Sciences, 302 Anheuser-Busch Natural Resources Building, University of Missouri,

Columbia, MO, USA

${ }^{6}$ North Central Research Station, 202 Anheuser-Busch Natural Resources Building, University of Missouri, Columbia, MO, USA

Email: ^wayne.arendt@USDA.gov, cary.tuckfield@ecostatys.com, jcmartinez@avesnicaragua.org, josezolotoff@gmail.com, juancarlosaves@gmail.com, Jennifer.reidy@gmail.com, frank.r.thompson@USDA.gov

How to cite this paper: Arendt, W.J., Tuckfield, R.C., Martínez-Sánchez, J.C., Reidy, J.L., Thompson III, F.R., Wunderle Jr., J.M. and Zolotoff, J.M. (2020) Avian Community Density and Distribution Patterns among Nicaraguan Conventional and Organic ShadeCoffee Plantations. Agricultural Sciences, 11, 27-53.

https://doi.org/10.4236/as.2020.111003

Received: October 24, 2019

Accepted: December 31, 2019

Published: January 3, 2020

Copyright $\odot 2020$ by author(s) and Scientific Research Publishing Inc. This work is licensed under the Creative Commons Attribution International License (CC BY 4.0).

http://creativecommons.org/licenses/by/4.0/

\begin{abstract}
We used a distance-sampling survey method and multivariate statistics to obtain a unique estimate of bird species density and seasonal variation in shade-coffee plantations. Our aim was to determine which cultivation practices among plantations contribute most to bird abundance. We conducted avian species counts at 200 points distributed across 10 shade-coffee plantations bordering the lower slopes of the Mombacho Volcano Natural Reserve, in western Nicaragua. We measured vegetation structure (coffee plants and overstory). We used principal components analysis (PCA) among 14 habitat variables to derive a single phyto-geoclimate summary measure (PGSM). We also used PCA to derive an avian abundance summary measure (AASM) from three bird survey variables, which proved to be a good predictor of bird density. We found higher bird species densities (AASM) in organic and traditional polyculture shade coffee plantations whose structurally complex and diverse overstory could be verified by PGSM. However, this finding was true only for birds that were habitat specialists. Our results provide further evidence for promoting organic coffee cultivation practices that maintain a structurally diverse overstory and help retain avian species richness and abundance in coffee plantations.
\end{abstract}




\section{Keywords}

Bird Density, Coffee Cultivation Practices, Monoculture, Organic, Polyculture, Spatial Distribution, Species Richness

\section{Introduction}

Elevated species richness, abundance and spatiotemporal use of traditional and diverse shade-coffee plantations by resident and migratory birds have been reported throughout the Neotropics [1]-[11]. However, not all coffee plantations provide similar quantities of food, shelter, and anti-predator benefits [12]. Prior research suggests that more diverse and structurally complex organic and traditional polycultures provide for a greater species diversity, abundance, reproduction, survivorship, and dispersal compared to newer, monocultural systems [5] [7] [13]-[18]. Coffee cultivation techniques that affect the structural and floristic diversity of the vegetation (e.g. pruning, application of chemicals) affect faunal populations [8]. Density, basal area and diversity of overstory trees in shade coffee and cacao plantations affect avian diversity and abundance and are often significantly correlated with numbers of forest specialist species [8] [19] [20]. Avian species richness is often the highest in low-intensity management sites near natural forest and forest remnants, and the lowest in high-intensity management sites far from natural forest and forest remnants [7] [21]-[27]. The size of forest remnants and coffee plantations also influences avian species richness, composition and site persistence [7] [19] [28] [29] [30] [31]. Broad-leaf and natural pine forest harbor more habitat specialists and endemics, especially insectivores, relative to coffee plantations [4]. However, shade-coffee plantations often harbor more forest and overwintering generalists, especially insectivores and nectarivores, owing to flowering overstory trees such as Inga spp. with their extrafloral nectaries and their ancillary insects, as well as species of open habitats such as pastures and grasslands [4] [20] [30] [32] [33].

In this study, we replicated several previous, mostly qualitative studies (but see exception [34]) to corroborate their results. But our primary goal was to better quantify the link between vegetational and avian ecological parameters due to coffee cultivation practices. To this end, we derived a phyto-geoclimate summary response measure (PGSM) and an avian abundance summary measure (AASM). These two novel metrics quantify vegetation structure and complexity in association with geoclimate variables, and bird density estimates from species richness and abundance measures, respectively. We predicted higher bird species richness and density in the more vegetatively complex organic and traditional polyculture shade coffee plantations than in coffee plantation monocultures and used PGSM and AASM to test this prediction. Our study objectives were, therefore, to: 1) use of multivariate statistics to characterize vegetation structure and complexity, as well as bird density estimates from species richness 
and abundance measures among organic, conventional, and transitional from coffee plantations; 2) test the statistical model prediction that bird species density/abundance is a positively increasing function of vegetation complexity and 3) determine which of the three coffee cultivation practices contributes most to bird species biodiversity.

\section{Materials and Methods}

\subsection{Study Area and Site Selection}

We conducted our study within the Mombacho Natural Reserve, Grenada, Nicaragua (Figure 1), by surveying 10 highland shade-grown coffee plantations located between 400 and 800 m.a.s.l. (mean elev. $=558.4 \mathrm{~m} \pm 124.89 \mathrm{SD}$ ) within a $7-\mathrm{km}$ radius inside a 6644-ha buffer zone on the lower slopes of the volcano bordering the Reserve (physical, topographical, edaphic, and vegetational characteristics of the volcano are summarized in [35]). All four organic farms studied were certified under the same standards established by the Organic Crop Improvement Association (OCIA International) under a project implemented by the Cooperative League of the United States of America (CLUSA) [35]. The four conventional and two transitional plantations were under a "commercial polyculture" management system (management types, tree species, physiognomy, and husbandry activities are summarized in Philpott et al. [10]).

\subsection{Habitat Measurements}

From each avian survey point (hereafter "plot" as described below), we ran four $25-\mathrm{m}$ transects to the north, south, east, and west to establish a $25-\mathrm{m}$ plot radius encompassing $\approx 0.2$ ha in which 14 vegetation-habitat (phyto-geoclimate) variables were measured (Table 1). Because the average plantation was about 62 ha in size, the average number of points was 20 per plantation and the overstory was homogeneous in each plantation, our sampling area is representative of the area used by the birds.

Elevation was measured using an altimeter into four strata $(\leq 10 \mathrm{~m}, 11-20 \mathrm{~m}$, $21-30 \mathrm{~m},>30 \mathrm{~m}$ ); we weighted each stratum by tree density to estimate total leaf volume $(\leq 10 \mathrm{~m}=$ density $\times 1 ; 11-20 \mathrm{~m}=$ density $\times 2 ; 21-30 \mathrm{~m}=$ density $\times$ 3 ; $>30 \mathrm{~m}=$ density $\times 4$ ) [10]. We measured maximum coffee plant height with a telescopic meter stick and height of the four tallest coffee plants measured along each of the four cardinal transects. We estimated coffee plant density by counting all vertical coffee stems within an approximate $1.5-\mathrm{m}$ lateral distance along the length of each transect [7]. We measured percent overstory cover with an ocular tube at 12 locations along each transect, starting $1 \mathrm{~m}$ from center point and then every $2 \mathrm{~m}$ along transects. We pointed the tube vertically into the shade overstory at the center of each point. We measured diameter of all stems $\geq 3 \mathrm{~cm}$ $1.3 \mathrm{~m}$ from the base (DBH); and counted the number of stems $<3 \mathrm{~cm}$ in $1.7-\mathrm{m}$ wide belt transects in the four cardinal directions from the plot center. We recorded the total number of species of overstory trees within the plot; trees were 


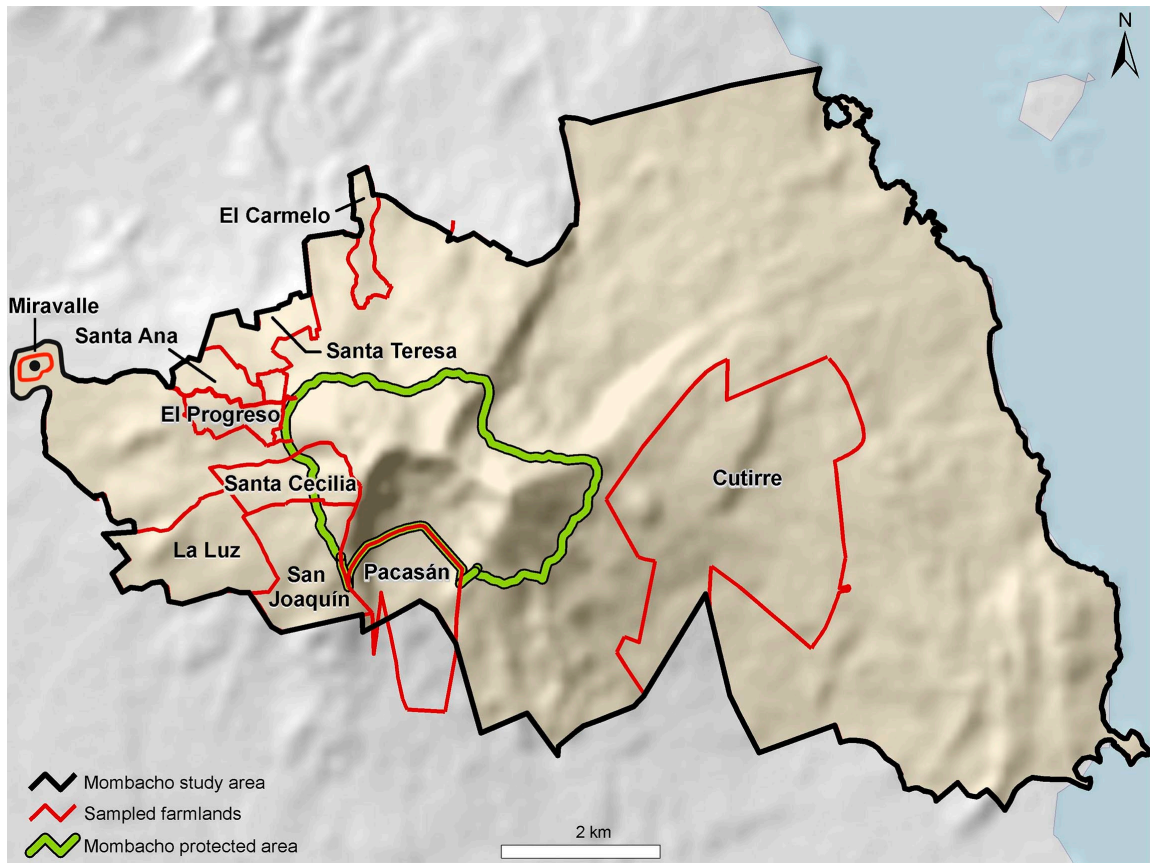

Figure 1. Ten, mid-elevation (mean = 558.4 m.a.s.l.), shade coffee plantations bordering the lower slopes of the Mombacho Volcano Natural Reserve in western Nicaragua.

Table 1. Results of principal components analysis of geo-climate and vegetation structure in 10 shade-coffee plantations bordering the lower slopes of the Mombacho Volcano Natural Reserve, Nicaragua (1998-1999). Coefficients for the 1st three principal components (eigenvectors) are given $(\mathrm{n}=200$ survey plots).

\begin{tabular}{cccc}
\hline Vegetation-Habitat Variable & PC1 & PC2 & PC3 \\
\hline Elevation (m) & -0.1303 & 0.7819 & 0.126 \\
Average wind speed & -0.2298 & 0.5954 & 0.0033 \\
Arcsine-square root (\% cloud cover) & 0.2381 & 0.5725 & 0.1328 \\
Number of trees/plot & -0.135 & 0.0578 & -0.6766 \\
Mean tree height & 0.7419 & -0.04 & 0.582 \\
SD tree height & 0.9111 & -0.2329 & -0.0348 \\
Maximum tree height & 0.9106 & -0.1537 & -0.0646 \\
Mean (No. of tree-height strata per plot) & 0.6639 & -0.0368 & 0.6264 \\
Number of tree species per point & 0.0657 & -0.5402 & -0.5014 \\
Arcsine-square root (\% canopy cover) & 0.2584 & -0.6037 & 0.1203 \\
Mean height of coffee plants/plot & 0.1062 & -0.3513 & 0.5144 \\
Mean (total leaf volume) & -0.3305 & 0.2508 & 0.6085 \\
Arcsine-square root (\% flowering) & -0.0634 & 0.3289 & -0.1422 \\
Arcsine-square root (\% with fruit) & 0.0412 & -0.3638 & 0.0277 \\
\hline
\end{tabular}

identified to species where possible, whereas 17 were classified simply as "morpho" species. We calculated the maximum height of overstory shade trees 100-m from their base with a clinometer. We measured total leaf volume of trees separated to determine if foliage (leaves only) was present or absent at a point. To meet the criteria of foliage present, at least $25 \%$ of the tube's sighting area had to be covered by foliage. We calculated average percent overstory cover for each of the two-hundred 0.2 -ha plots $\left(\left[\left(3.14 \times 25 \mathrm{~m}^{2}\right)\right] \times 0.0001\right)$. We recorded fruit and flower abundance of overstory trees on a scale from 0 to 4 , representing percen- 
tages $(0 \%, 25 \%, 50 \%, 75 \%, 100 \%)$ within four imaginary quadrants superimposed on the tree's canopy, i.e., $0 \%$ fruit when all four quadrants were empty, $100 \%$ when fruit was observed in all four quadrants; these measures enabled a comparison of avian density in relation to seasonal variation.

\subsection{Avian Surveys}

We conducted 10-min, unlimited radius surveys at 200 points that were spaced ca.100 $\mathrm{m}$ apart and distributed randomly across the 10 shade-coffee plantations. Only detections from within a plantation were recorded. We surveyed 83, 63 and 54 plots in 4 organic, 4 conventional, and 2 transitional plantations, respectively (described and tabular summaries in [35]). Each point was surveyed between sunrise and $1030 \mathrm{hr}$ (CST: Central Standard Time) in good weather conditions (no rain or excessive wind) once in each of four periods: 1) 25 February - 1 March 1998; 2) 22 July - 5 August 1998; 3) 10 November - 21 November 1998; and 4) 16 March - 14 April 1999. Two to four observers surveyed different points in each period. To eliminate double-counting of vociferous species such as parrots and jays, we conducted a means comparison test [7] by comparing mean detections per point at 100 vs. $200 \mathrm{~m}$ (results were: $P=0.874$ ). Data were truncated in the outer bins, further eliminating the possibility of double counting highly vocal species. Observers recorded the number of individuals of all species detected during the count, estimated distance to detected birds or to the center of the cluster, i.e., groups of two or more [36], and categorized the observation as occurring in the coffee plants within the understory or the shade-tree overstory. The chronological order of plot visits was randomized to minimize temporal bias in bird detectability throughout the morning. Aerial birds were not recorded unless they alighted in vegetation during the 10 -min count. Because cloud cover can be a major hindrance to avian surveys at high elevation cloud forest sites, we estimated percent cloud cover on a scale from 0 - 100 in increments of $25(0=$ clear skies, $100=$ overcast $)$. Similarly, high winds can drown out bird vocalizations on exposed slopes. Therefore, we recorded wind speed using the Beaufort scale (http://www.spc.noaa.gov/faq/tornado/beaufort.html).

\subsection{Avian Species Richness, Abundance and Density Estimation}

We compared species richness and abundance by ANOVA statistical methods among plantations grouped by the three coffee cultivation practices: Conventional, Organic and Transitional. We estimated bird density per hectare using distance models [37] for species with $\geq 30$ observations in program Distance 6.0 [36]. This method accounts for birds present but not detected by fitting a detection function, $P$, to observed counts for a given distance from the observer. We filtered the data by species and distances $\geq 0$ to account for missing distance values. We truncated data to detections with distances $\leq 40 \mathrm{~m}$ and grouped observations by $0-10 \mathrm{~m}, 10-20 \mathrm{~m}, 20-40 \mathrm{~m}$, and $40-60 \mathrm{~m}$, except for raucous species that were audible at long distances: Yellow-throated Euphonia (Euphonia 
hirundinacea) and Hoffmann's Woodpecker (Melanerpes hoffmannii) (truncated at $85 \mathrm{~m}$ ) and Keel-billed Toucan (Ramphastos sulfuratus) (truncated at $100 \mathrm{~m}$ ). The truncation distance for each species was determined by the maximum distance at which the species was audible, except for the toucan, which, although audible at distances greater than $100 \mathrm{~m}$, was truncated at our designated maximum distance of $100 \mathrm{~m}$. We did not include birds detected more than $40 \mathrm{~m}$ in the direction of points behind us as not to count the same individuals in areas of overlap. We used a half-normal detection function with a cosine series expansion to fit the data. Because each point was visited four times, we included survey effort as a multiplier, which allowed us to divide density by effort. Because some species, e.g., parrots, were often detected in groups, designated as clusters, we included the total number of individuals detected per point at each distance and specified the size-bias regression method to estimate group size. For species with $>50$ detections, we compared support for the global model internal to the Distance 6.0 software, with models including observer, period, and observer + period as covariates in the multiple covariate distance sampling (MCDS) engine. The most supported model had the lowest Akaike's Information Criterion $\left(\mathrm{AIC}_{c}\right.$ ) value (tabulated as $\Delta \mathrm{AIC}_{c}=0$ ). We report $\Delta \mathrm{AIC}_{c}$ from models evaluated for each species (Table 2). For species with fewer than 50 detections, we estimated density per hectare using a global detection function. We report detection probability $(P)$, effective detection radius (EDR), cluster size, and density for each management type based on the top model (Table 3 ).

Table 2. Support for candidate models for 14 species with $>50$ detections from point counts in Nicaragua, 1998-1999. Shown here are number of parameters $(\mathrm{K})$ and $\Delta \mathrm{AIC}_{\mathrm{c}}$ (difference in $\mathrm{AICc}$ from the most supported model to the evaluated model; $\Delta \mathrm{AIC} \mathrm{c}_{\mathrm{c}}$ for top model is 0 ) for each model. The global model derived a global detection function; observer, period, and observer + period models derived the detection function using the respective covariate (see text). Species codes are defined in the Appendix.

\begin{tabular}{|c|c|c|c|c|c|c|c|c|}
\hline \multirow[b]{2}{*}{ Species } & \multicolumn{2}{|c|}{ Global } & \multicolumn{2}{|c|}{ Observer } & \multicolumn{2}{|c|}{ Period } & \multicolumn{2}{|c|}{ Observer + Period } \\
\hline & $\mathrm{K}$ & $\triangle \mathrm{AICc}$ & $\mathrm{K}$ & $\triangle \mathrm{AICc}$ & $\mathrm{K}$ & $\triangle \mathrm{AICc}$ & $\mathrm{K}$ & $\Delta \mathrm{AICc}$ \\
\hline CALFOR & 1 & 21.72 & 4 & 6.70 & 4 & 9.17 & 7 & 0.00 \\
\hline CANMOD & 1 & 7.50 & 5 & 0.00 & 4 & 11.48 & 8 & 2.44 \\
\hline CHILIN & 2 & 15.47 & 4 & 0.00 & 4 & 17.46 & 7 & 2.23 \\
\hline EUPHIR & 1 & 5.27 & 5 & 1.62 & 4 & 9.12 & 8 & 0.00 \\
\hline HYLDEC & 1 & 0.00 & 4 & 1.88 & 4 & 4.37 & 7 & 7.85 \\
\hline HYLELI & 1 & 16.45 & 4 & 0.00 & 4 & 15.82 & 8 & 0.63 \\
\hline MELHOF & 2 & 43.66 & 5 & 14.17 & 5 & 32.26 & 8 & 0.00 \\
\hline MYITUB & 2 & 7.20 & 4 & 0.00 & 5 & 10.40 & 7 & 1.82 \\
\hline OREPER & 1 & 0.00 & 4 & 4.57 & 3 & 2.59 & 6 & 7.31 \\
\hline PSAMON & 1 & 22.92 & 5 & 0.02 & 4 & 21.76 & 7 & 0.00 \\
\hline RAMSUL & 1 & 2.17 & 4 & 0.00 & 4 & 5.62 & - & - \\
\hline SETPET & 1 & 14.44 & 4 & 1.18 & 3 & 6.14 & 6 & 0.00 \\
\hline THRPLE & 2 & 27.05 & 5 & 12.05 & 5 & 17.21 & 8 & 0.00 \\
\hline TOLSUL & 2 & 8.65 & 4 & 4.09 & 4 & 5.01 & 6 & 0.00 \\
\hline
\end{tabular}


Table 3. Number of observations $(\mathrm{N})$, detection probability $(P)$, effective detection radius (EDR), mean cluster size, and density per hectare by management system (95\% CI) from point counts in Nicaragua, 1998-1999. We surveyed 372, 332 , and 96 points in conventional, organic, and transitional farms, respectively.

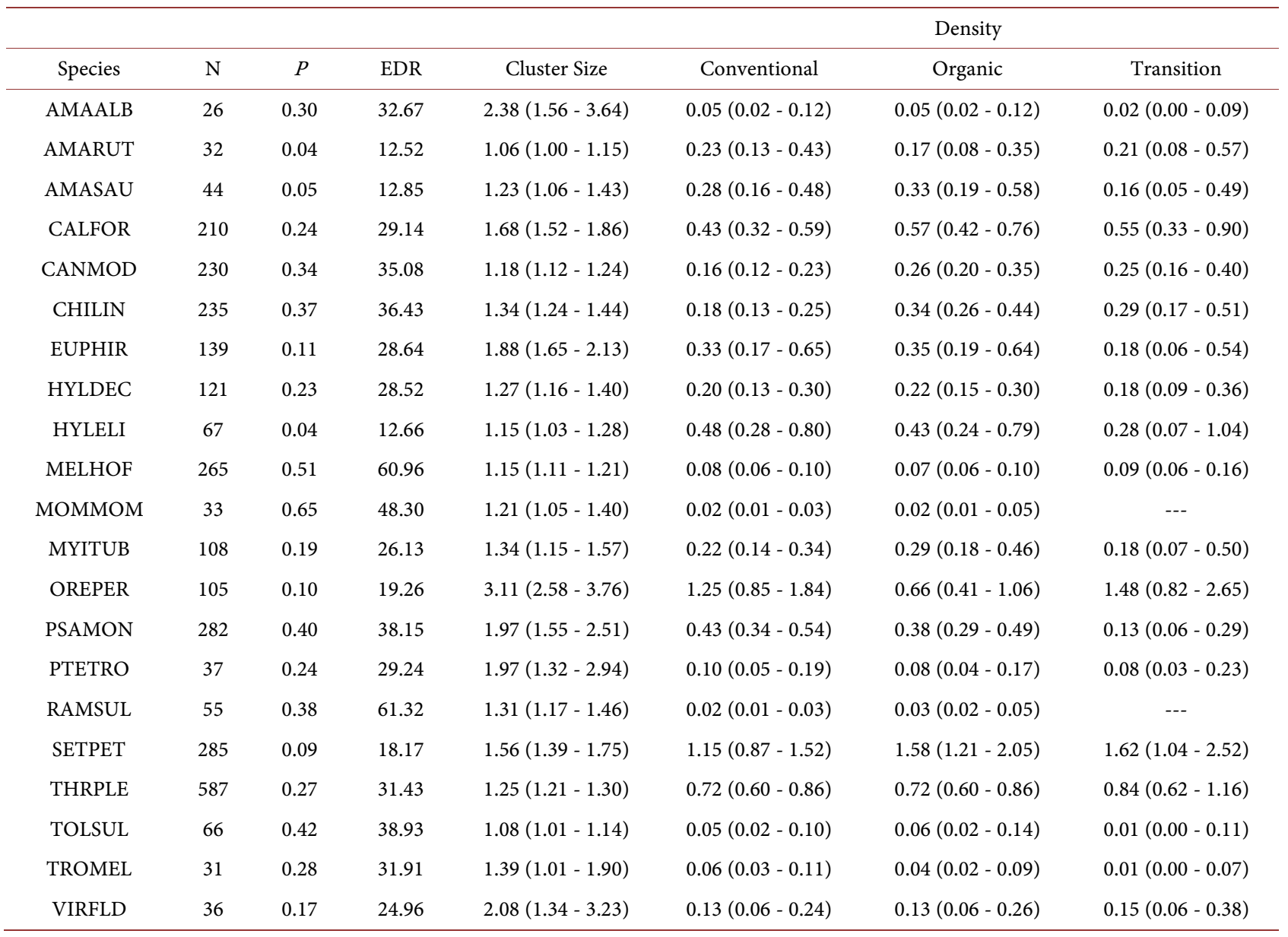

\subsection{Statistical Design and Modeling}

To examine patterns of seasonal bird density per hectare, we report density estimates for each species by period (Table 4), which are explained below.

Habitat variables not otherwise quantified on a measurement scale, but estimated as percentages (e.g., canopy cover and trees with flowers or fruits) were normalized via the arcsine-square root transformation, a common variancestabilizing technique.

From the bird species observation data, we selected only those species with $>=$ 30 detections for further analysis. These species were considered to have sufficient sample size for comparison. The intent of the design was to estimate the effects of shade-coffee cultivation practice (management system) and sampling period on a bird species diversity-richness response measure using simple linear regression (SLR) [38]. Species with a larger number $(\geq 50)$ of detections allowed us to model the co-variation in this response with phyto-geoclimate variables per cultivation practice as well using the method of analysis of covariance (ANCOVA) [38]. 
Table 4. Bird density (95\% CI) per hectare estimated using distance-based models to account for imperfect detection for each survey period (Period 1: 25 February - 1 March 1998; Period 2: 22 July - 5 August 1998; Period 3: 10 November - 21 November 1998; and Period 4: 16 March - 14 April 1999) from point counts in Nicaragua, 1998-1999. We surveyed 200 points per period.

\begin{tabular}{|c|c|c|c|c|c|}
\hline \multirow[b]{2}{*}{ Species } & \multirow[b]{2}{*}{$\mathrm{N}$} & \multicolumn{4}{|c|}{ Density } \\
\hline & & Period 1 & Period 2 & Period 3 & Period 4 \\
\hline AMAALB & 26 & $0.06(0.03-0.14)$ & $0.02(0.01-0.07)$ & $0.03(0.01-0.09)$ & $0.08(0.04-0.19)$ \\
\hline AMARUT & 32 & $0.18(0.08-0.40)$ & $0.23(0.10-0.50)$ & $0.15(0.07-0.36)$ & $0.26(0.12-0.54)$ \\
\hline AMASAU & 44 & $0.18(0.08-0.40)$ & $0.10(0.04-0.28)$ & $0.08(0.03-0.23)$ & $0.78(0.48-1.28)$ \\
\hline CALFOR & 210 & $0.84(0.65-1.09)$ & $0.36(0.26-0.51)$ & $0.32(0.21-0.46)$ & $0.49(0.36-0.65)$ \\
\hline CANMOD & 230 & $0.25(0.19-0.34)$ & $0.27(0.20-0.38)$ & $0.21(0.16-0.29)$ & $0.12(0.08-0.19)$ \\
\hline CHILIN & 235 & $0.36(0.27-0.48)$ & $0.40(0.30-0.52)$ & $0.12(0.08-0.19)$ & $0.16(0.11-0.24)$ \\
\hline EUPHIR & 139 & $0.06(0.03-0.14)$ & $0.50(0.29-0.84)$ & $0.40(0.24-0.68)$ & $0.31(0.18-0.54)$ \\
\hline HYLDEC & 121 & $0.07(0.03-0.13)$ & $0.23(0.14-0.37)$ & $0.36(0.25-0.53)$ & $0.15(0.10-0.25)$ \\
\hline HYLELI & 67 & $0.96(0.62-1.49)$ & $0.16(0.07-0.35)$ & $0.23(0.10-0.54)$ & $0.39(0.22-0.70)$ \\
\hline MELHOF & 265 & $0.09(0.07-0.11)$ & $0.08(0.06-0.10)$ & $0.07(0.05-0.09)$ & $0.08(0.06-0.10)$ \\
\hline MOMMOM & 33 & $0.06(0.03-0.12)$ & $0.00(0.00-0.01)$ & --- & $0.01(0.00-0.02)$ \\
\hline MYITUB & 108 & $0.21(0.12-0.36)$ & $0.27(0.16-0.44)$ & $0.31(0.20-0.49)$ & $0.18(0.11-0.29)$ \\
\hline OREPER & 105 & $0.94(0.58-1.53)$ & --- & $2.64(1.82-3.83)$ & $0.55(0.30-1.01)$ \\
\hline PSAMON & 282 & $0.52(0.41-0.66)$ & $0.28(0.20-0.38)$ & $0.30(0.23-0.40)$ & $0.38(0.29-0.50)$ \\
\hline PTETRO & 37 & $0.16(0.08-0.30)$ & $0.06(0.02-0.16)$ & $0.02(0.00-0.07)$ & $0.13(0.07-0.25)$ \\
\hline RAMSUL & 55 & $0.03(0.02-0.05)$ & $0.03(0.02-0.05)$ & $0.01(0.00-0.03)$ & $0.01(0.00-0.02)$ \\
\hline SETPET & 285 & $1.53(1.20-1.96)$ & --- & $2.13(1.69-2.69)$ & $1.86(1.47-2.36)$ \\
\hline THRPLE & 587 & $0.53(0.42-0.67)$ & $1.04(0.88-1.23)$ & $0.65(0.53-0.79)$ & $0.71(0.59-0.85)$ \\
\hline TOLSUL & 66 & --- & $0.10(0.06-0.20)$ & $0.04(0.02-0.08)$ & $0.04(0.02-0.09)$ \\
\hline TROMEL & 31 & $0.03(0.01-0.09)$ & $0.06(0.03-0.14)$ & $0.01(0.00-0.05)$ & $0.09(0.04-0.17)$ \\
\hline VIRFLD & 36 & $0.03(0.01-0.11)$ & $0.19(0.09-0.38)$ & $0.17(0.08-0.36)$ & $0.13(0.06-0.29)$ \\
\hline
\end{tabular}

The multivariate method of principal components analysis (PCA) [39] was used as a dimensionality reduction tool among the 14 phyto-geoclimate variables (i.e. dimensions). Each of the 14 principal components is ordered in magnitude (PC1, PC2, .., PC14) in accounting for the largest to the smallest percentage of total variation explained among the 14 original variables. We employed the first principal component (PC1) exclusively as a univariate summary measure. It characterizes in one dimension the largest amount of environmental information at each of the 200 avian sampling plots among the 10 coffee plantations. This method partitions the information in a correlation matrix comprising ${ }_{14} \mathrm{C}_{2}=91$ combinations of pairwise correlations among the phyto-geoclimate variables [40]. The first eigen value of that matrix is also an indication of the number of dimensions represented in our phyto-geoclimate summary response measure (PGSM) or PC1. Unlike the foliage height diversity (FHD) measure of MacArthur and MacArthur [41], PGSM characterizes the habitat on a more continuous scale instead of just 2 to 4 height classes. 
In addition, multivariate analysis of variance (MANOVA) and discriminant function analysis (DFA) [39] were used to discriminate differences among the vegetation-habitat characteristics of shade-coffee plantations grouped by organic, conventional, and transitional coffee cultivation practices. MANOVA determined the strength of evidence in favor of the hypothesis that the multivariate phyto-geoclimate measurement response vectors differ significantly among the three coffee cultivation practices [39]. DFA also identifies those phyto-geoclimate variables that contribute most to the discrimination among these three groups of measurements, that is, among their multivariate mean vectors called centroids [42].

DFA was conducted via a stepwise forward-selection procedure [42]. Tree species richness and diversity estimates were obtained using EstimateS 8.2 software [43].

To summarize bird abundance at each of the 200 sampling plots, we performed a similar PCA using three bird abundance variables: total bird count, mean distance to detection, and the standard deviation of detection distance. This PC1 is referred to as the avian abundance summary measure (AASM). Density estimates using the Distance 6.0 software [36] for each of 21 species were also calculated for each of the four sampling periods, for each coffee cultivation practice. Shannon-Wiener and Simpson's diversity indices [44] were used to compare species diversity among management types.

We used SLR by the standard least squares method to compare the AASM scores for bird abundance to the calculated bird density measurements among the four sampling periods for all bird species. SLR was also used to determine the dependence, if any, of AASM on PGSM. Since there is measurement error in both, an orthogonal regression [45] was also performed for an alternate and perhaps more accurate explanation of the relationship between the two summary measures.

The AASM was further aggregated by sampling plot for each of two species groups-one group with relatively steep (large valued) SLR slopes between AASM vs bird density and another group with relatively shallow (small valued) SLR slopes.

We used an analysis of covariance (ANCOVA) model [38] to discover the effects of coffee cultivation practices on the AASM after accounting for its expected relation with the PGSM. All statistical analyses were performed using the JMP` $\left.{ }^{\circledR} 46\right]$.

\section{Results}

\subsection{Vegetation and Habitat Analysis}

We found that tree species diversity is higher under organic and transitional management types compared to conventional. The Shannon-Wiener diversity index was highest in organic farms (organic $=2.44$, conventional $=2.28$, and transitional $=2.29)$. Although the Simpson's Diversity index was higher in tran- 
sitional farms, it is more similar in magnitude to organic than conventional farms (organic $=5.54$, conventional $=5.01$, and transitional $=5.67$ ). All reported diversity values are average calculations among census plots within management types.

PCA of the 14 phyto-geoclimate variables showed that PC1 (PGSM hereafter) accounted for $27 \%$ of the total variation among these variables while PC2 and PC3 each explained an additional 18\% and 9.4\%, respectively (Table 1). The four variables in PC1 with the largest eigenvector coefficients and therefore greatest contributing information to the PGSM were mean tree height, SD tree height, maximum tree height, and mean number of tree-height strata per plot (Table 1). The cumulative magnitude of the three largest and corresponding eigen values was 7.6 indicating that almost 8 of the 14 phyto-geoclimate measurement dimensions could be summarized from the 1 st three PCs, approximately 4 dimensions in the 1st PC (PGSM) alone.

A subset of five phyto-geoclimate variables were selected by the stepwise DFA modeling method that account for the statistically significant $(P<0.001)$ MANOVA differences among the three coffee cultivation practices. These variables are percent cloud cover, percent canopy cover, elevation, mean number of tree height strata per plot, and mean height of coffee plants per plot. Measurement data for these five variables are summarized in Figure 2 by coffee cultivation practice.

MANOVA showed a significant difference (Wilk's lambda $=0.338, \sim \mathrm{F}_{28,368}=$ 9.46, $P<0.001)$ among the three coffee cultivation practices corresponding to differences among the 14 phyto-geoclimate variables. The concomitant DFA results indicate significant group (cultivation practice) separation among the 200 avian sample locations. This is illustrated in a scatter-plot of the 1 st vs. 2 nd discriminant functions (DF1 or DF2), or canonical variate scores for each group (Figure 3). The most important variables that contribute to the discrimination among the coffee cultivation practices (group centroids) in DF1 were percent cloud cover $(0.9192)$, mean number of tree-height strata per plot $(0.7208)$, percent canopy cover $(-0.5302)$, and elevation $(-0.4640)$. Those contributing most to DF2 were mean coffee plant height $(-0.8404)$, SD of tree height $(-0.6510)$, mean total leaf volume/tree height stratum ( -0.6340$)$, and elevation (0.6257).

\subsection{Bird Species Density vs. Coffee Cultivation Practice}

We documented 6110 audio-visual detections of 98 bird species, of which 13 were identified only to genera (Appendix). The average number of species (richness) among the two transitional plantations (avg. = 57) and the four organic plantations (avg. = 51) was greater than that of the four conventional plantations (avg. $=47)$, although not significantly significant $(\mathrm{p}>0.05)$ (Table 5). All bird species were more abundant in the overstory than in coffee plants, except for two species of wren, Cantorchilus modestus and Thryophilus pleurostictus. 

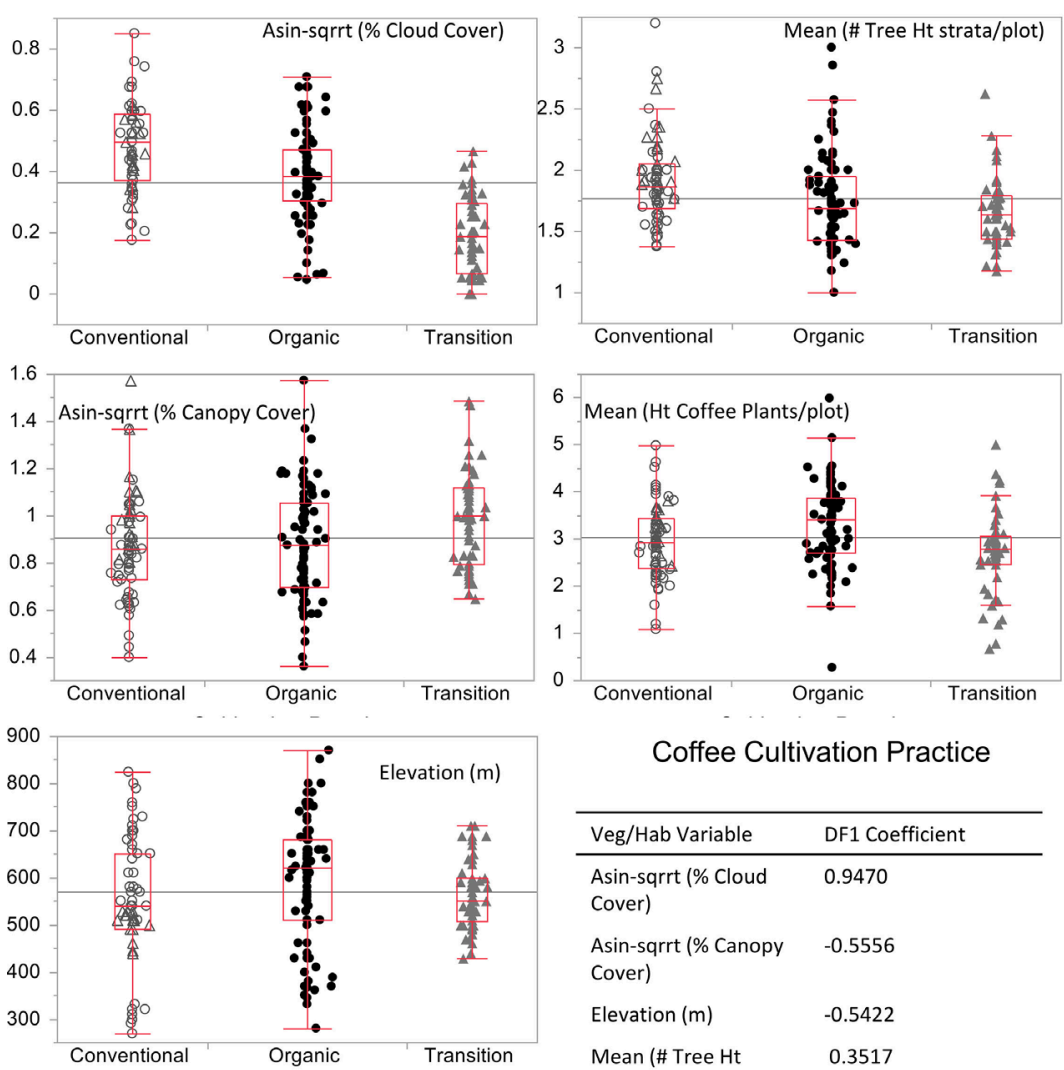

Coffee Cultivation Practice

Coffee Cultivation Practice

\begin{tabular}{ll}
\hline Veg/Hab Variable & DF1 Coefficient \\
\hline $\begin{array}{l}\text { Asin-sqrrt (\% Cloud } \\
\text { Cover) }\end{array}$ & 0.9470 \\
$\begin{array}{l}\text { Asin-sqrrt (\% Canopy } \\
\text { Cover) }\end{array}$ & -0.5556 \\
Elevation (m) & -0.5422 \\
$\begin{array}{l}\text { Mean (\# Tree Ht } \\
\text { strata/plot) }\end{array}$ & 0.3517 \\
$\begin{array}{l}\text { Mean (Ht Coffee } \\
\text { Plants/plot) }\end{array}$ & 0.2315 \\
\end{tabular}

Figure 2. Boxplots for 5 of the 14 vegetation/habitat variables with the largest (absolute value) 1st Discriminant Function (DF1) coefficients in order of entry to a stepwise DF analysis, which show the relative importance of each to the discrimination among groups of sampling plots corresponding to the three shade-coffee cultivation methods.

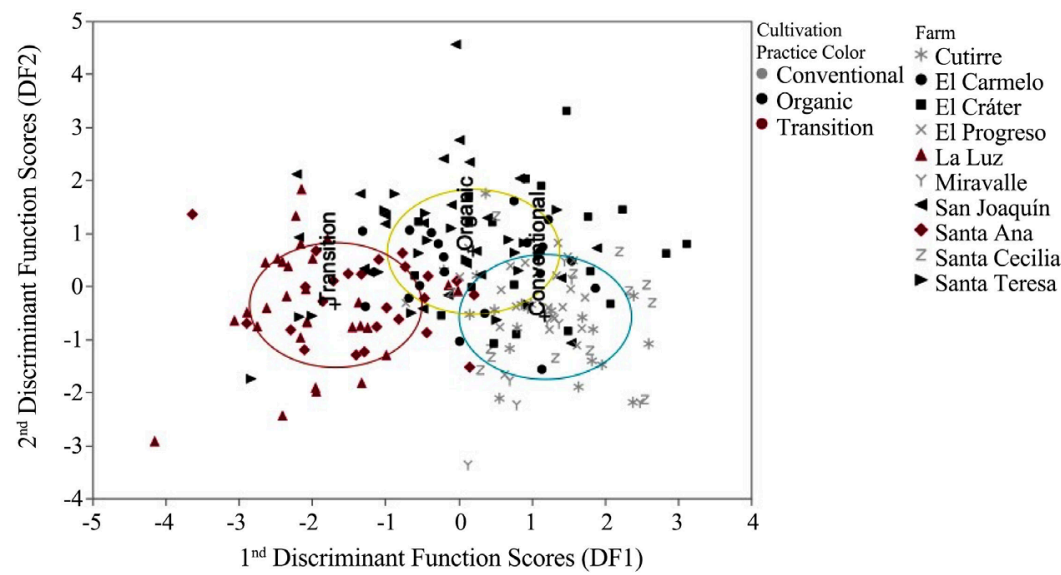

Figure 3. A scatterplot of the scores of the first two discriminant functions (DF1 and DF2) obtained by the stepwise DFA method. This figure distinguishes the groups of farms that use each of the three coffee cultivation practices (marker color) as well as the farms themselves (marker symbols) - see legends. In addition, the group centroids (DF1 mean coordinate, DF2 mean coordinate) is signified by the + marker. The ellipses represent the areas containing $50 \%$ of the scores for each DF group. 
Table 5. Total number of species, detections, and relative abundance of birds per farm and management type.

\begin{tabular}{|c|c|c|c|c|c|c|c|c|c|c|}
\hline \multicolumn{2}{|l|}{ Cultivation Practice } & \multicolumn{2}{|c|}{ Conventional } & \multicolumn{3}{|c|}{ Transitional } & \multicolumn{4}{|c|}{ Organic } \\
\hline Farm & Cutirre & El & Miravalle & Santa & $\mathrm{La}$ & Santa & $\mathrm{El}$ & Pan- & San & Santa \\
\hline & & Progreso & & Cecilia & Luz & Ana & Carmelo & casán & Joaquín & Terresa \\
\hline Total Detections & 940 & 465 & 213 & 538 & 851 & 683 & 679 & 679 & 546 & 516 \\
\hline Total Species & 68 & 40 & 35 & 43 & 58 & 56 & 57 & 50 & 47 & 48 \\
\hline $\begin{array}{l}\text { Relative Abundance } \\
\text { (avg. detects./species) }\end{array}$ & 13.82 & 11.63 & 6.09 & 12.51 & 14.67 & 12.20 & 11.91 & 13.58 & 11.62 & 10.75 \\
\hline
\end{tabular}

The PC1 (AASM hereafter) from this PCA explained $82 \%$ of the variation among its three constituent variables, viz., bird count, mean distance to the detected individual/cluster, and the standard deviation of that detection distance. The AASM also summarized 2.5 of the 3 dimensions (see Methods above). The summarized information constituting this dimensionality-reduced latent variable (AASM) positively correlated with the bird species density estimates obtained by the DISTANCE 6.0 software. SLR examined this relationship between species density and AASM among periods. Of the 21 most frequently detected ( $\geq 50$ ) bird species, five have similar and more steeply (large) positive SLR slopes in the graph of bird density against AASM (Figure 4(A)) when compared to the remaining 16 species (Figure 4(B)) with less steep (small) but positive slopes. SLR slopes of both species groups were statistically significant $(P<0.001)$. After examination of these two species groups, the former comprises five habitat generalists, whereas the latter comprises 16 habitat specialists.

Bird densities (per hectare) for the subset of 21 species with $\geq 50$ detections varied among dietary guilds (Figure $5(\mathrm{~A})$ ) and in relation to vegetation strata, seasonality, and tree reproductive phenology (spring and fall flowering and fruiting peaks) (Figure 5(B)).

The entire data set was then re-aggregated to produce a new response vector from three variables, viz., total count, mean detection distance, and the standard deviation of detection distance, for each of the two species groups defined in Figure 4. A different PCA was performed to produce a separate AASM for each species group (habitat generalist and specialist, or $\mathrm{AASM}_{\mathrm{g}}$ and $\mathrm{AASM}_{\mathrm{s}}$ ) among sampling plots, plantations, and periods. The $\mathrm{AASM}_{\mathrm{g}}$ and $\mathrm{AASM}_{\mathrm{s}}$ coefficients of the three variables that comprise them were similar for each species group $(0.4435,0.6473,0.6200$ and $0.3745,0.6711,0.6398$, respectively). Each of these two new response variables also explained $75 \%$ and $69 \%$ of the total variation and summarized 2.5 and 2.1 of the 3 response dimensions for each species group, respectively.

A 2-way ANOVA model was fit to the surrogate density estimate $\mathrm{AASM}_{\mathrm{g}}$ or $\mathrm{AASM}_{\mathrm{s}}$ as a function of coffee cultivation practice and period main effects, and included an interaction effect. For the generalist species group, the results showed no effect due to cultivation practice, but a significant period effect $(P<$ 
0.001) due to low bird counts for these species in period 2 (Figure 6(A)). Neither was there a significant cultivation practice by period interaction effect. In contrast, the specialist species group showed a significant $(P<0.001)$ cultivation practice effect (Figure 6(B)), but no period or interaction effect.

Subsequent ANCOVA models were also fit separately for $\mathrm{AASM}_{\mathrm{g}}$ and $\mathrm{AASM}_{\mathrm{s}}$ to test for a cultivation practice effect after accounting for the relationship with the covariate (i.e., the PGSM). Results showed no significant regression relation between the AASM $\mathrm{g}$ vs. PGSM scores, or any evidence that the slope of this relation differs from zero among cultivation practices (Figure 7(A)). However, results for the habitat specialists showed a significantly $(P=0.008)$ positive overall regression relation between the $\mathrm{AASM}_{\mathrm{s}}$ vs. PGSM. In addition, at the average value of the covariate (vertical dotted line at zero Figure $7(B)$ ), the least squares mean bird abundance/density was significantly higher in organic coffee plantations, than in either conventional or transitional coffee plantations $(P=0.07$ and $P=0.005$, respectively). Note that we regard a $7 \%$ chance of Type I error as indistinguishable from $5 \%$.
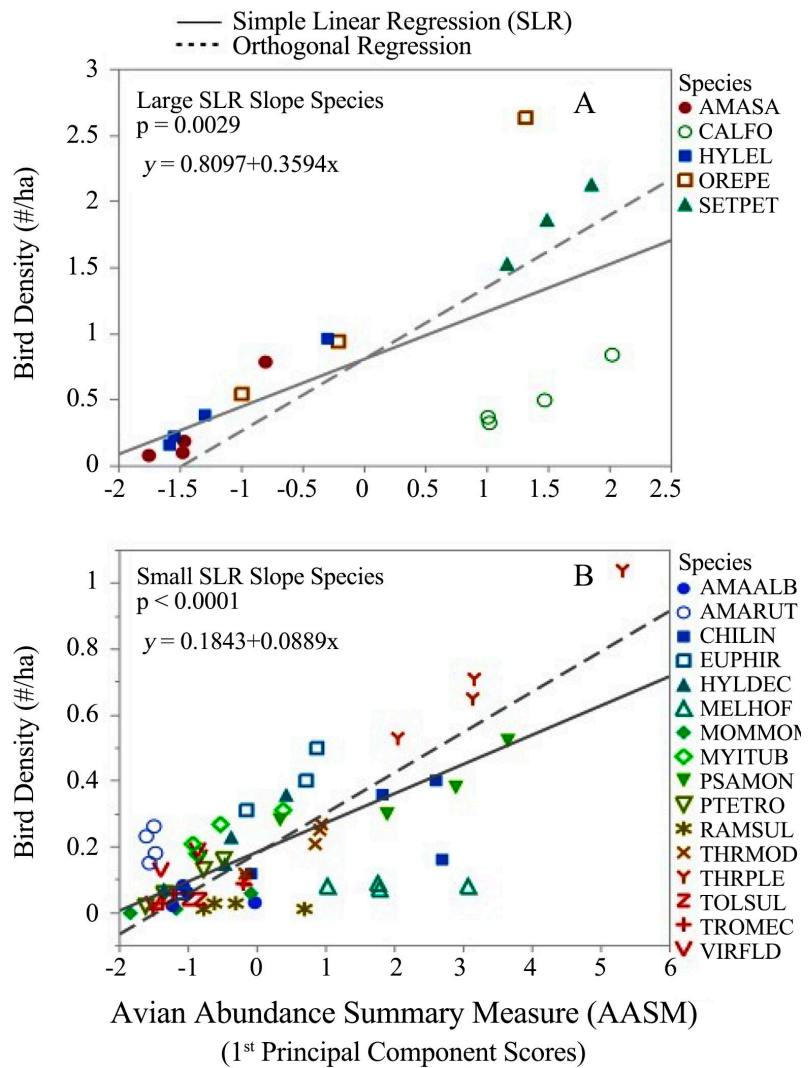

Figure 4. Regression analyses showing the statistically significant and positive relationship between bird density per hectare (sensu DISTANCE 6.0 software calculation) and the Avian Abundance Summary Measure (AASM) or 1st principal component scores (PC1) from 3 bird abundance measures (see text). Five species (A) have a larger SLR slope than the remaining 16 species (B). Orthogonal fits assume measurement error in both variables. 

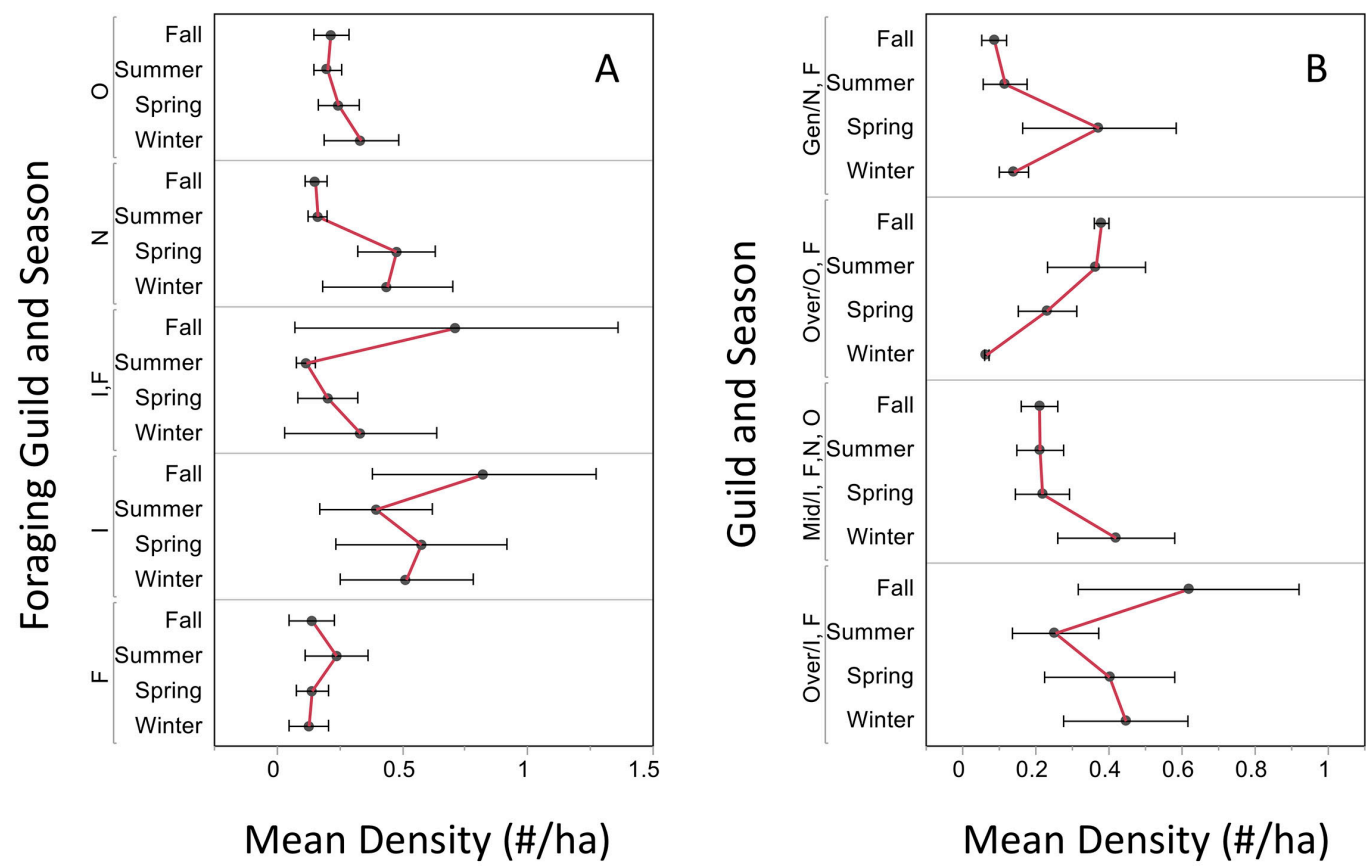

Figure 5. Density of birds per hectare by: (A) dietary guild; and (B) habitat strata in relation to spring and fall flowering and fruiting peaks in Mombacho shade-coffee overstory. Habitat strata: understory, shrub, mid-canopy and trunk specialists (Mid), overstory specialists (Over), strata generalists (Gen). Dietary guilds: frugivore $(\mathrm{F})$; insectivore $(\mathrm{I})$; nectarivore $(\mathrm{N})$; ominivore $(\mathrm{O})$. "Winter" (25 February - 1 March 1998); "spring" (16 March - 14 April 1999) "summer" (22 July - 5 August 1998); "fall" (10 November - 21 November 1998).
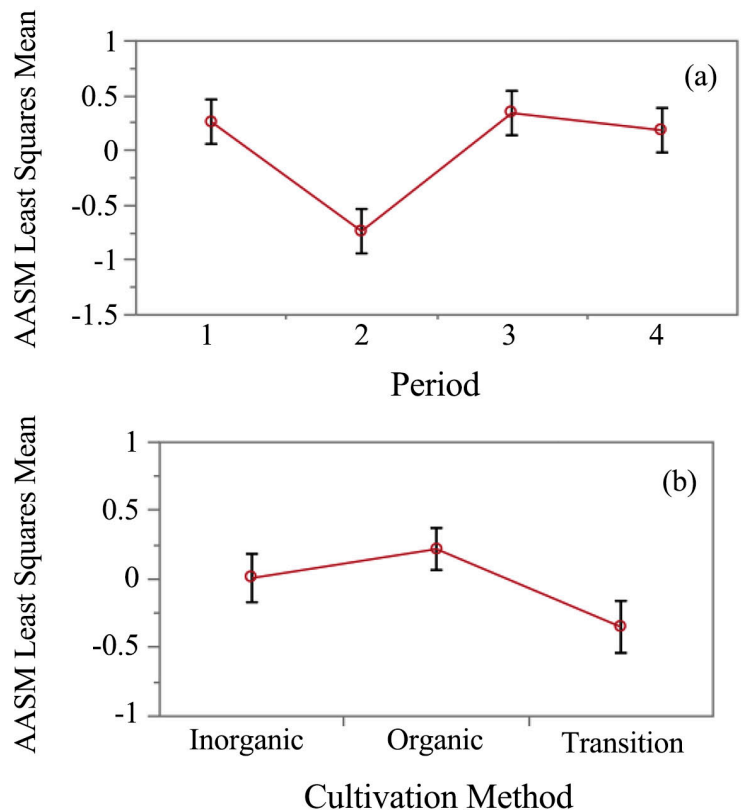

Figure 6. Least squares means (with standard error bars) for the AASM measure of bird density (see text) as a function of a 2-way ANOVA model using sampling period and coffee cultivation method as main effects, with interaction. Statistically significant $(p<0.05)$ main effect results are presented for the large SLR slope (A) and small SLR slope (B) bird species. See Figure 4 for SLR slope illustration. 


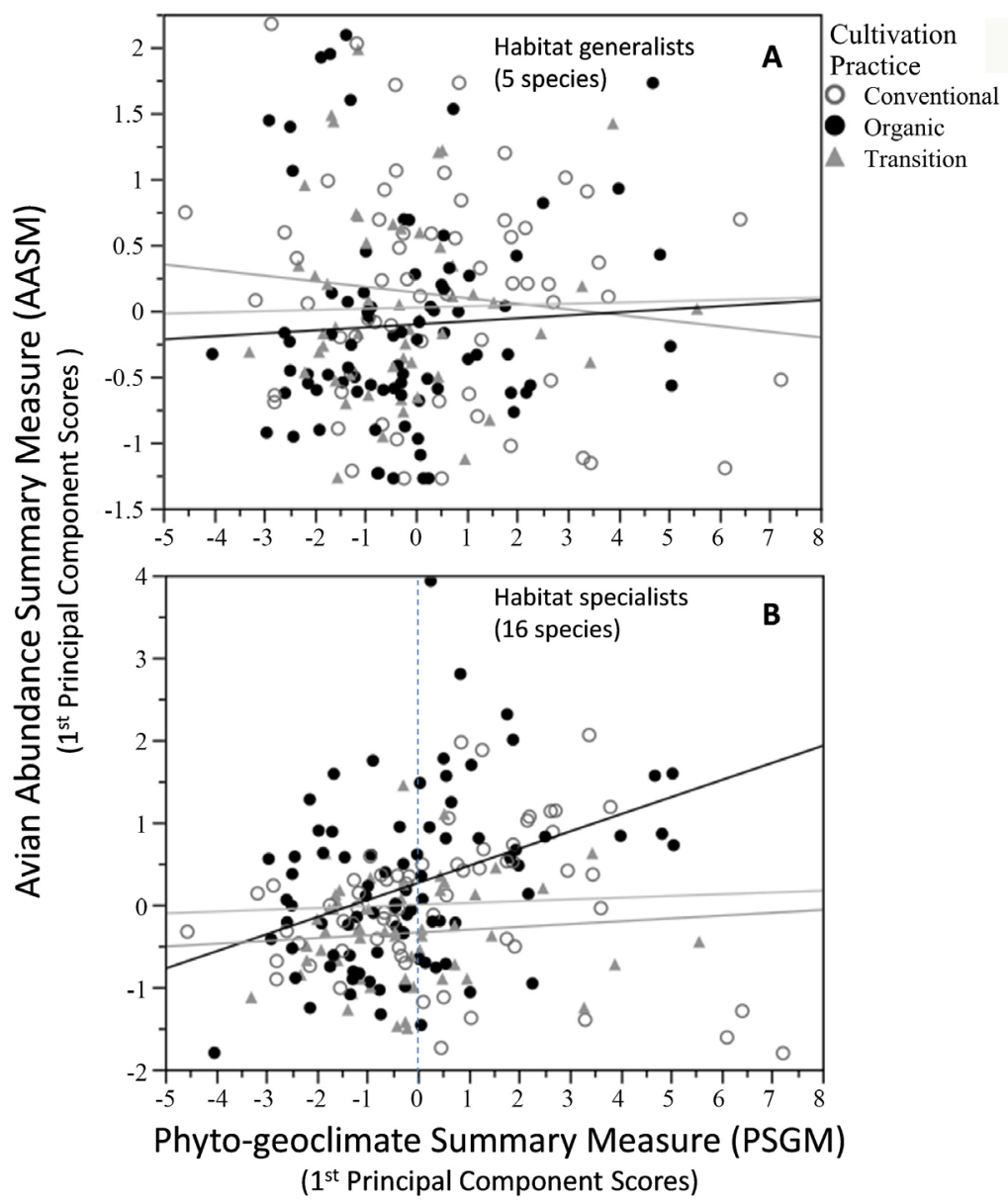

Figure 7. Simple linear regression fit of the dimensionality reduced summary measures (PC1 scores) for bird abundance (AASM) vs vegetation/habitat (PGSM) variables. (A) Habitat generalist species show no significant slopes regardless of cultivation practice. (B) Habitat specialist or discriminating species show significant $(P<0.001)$ and positive slope in organically cultivated coffee farms.

\section{Discussion}

\subsection{Habitat Factors Affecting Avian Communities}

We have shown by the methods of PCA and DFA, that diverse vegetation and complex native canopy structure in organic shade-coffee plantations result in greater avian species diversity, richness, abundance, and composition as reported in previous studies [15] [18] [47]. More importantly, we have added to the contemporary collective knowledge of bird abundance in coffee plantations by deriving two novel metrics (PGSM and AASM) that quantify species densities among coffee management systems, seasonally and under disparate climatic conditions. The phyto-geoclimate summary measure or PGSM represents the aspects of vegetation structure and canopy composition that are positively related to greater avian habitat stratification and demonstrates that coffee overstory is similar to natural forest harbors of greater bird diversity, abundance [10] [26] [27] [35] [47] [48] [49] [50] and density [51] [52]. 
DF1 represents a measure of bird habitat type "positioning" (Figure 2). Positive DF1 coefficients meant that as percent cloud cover and mean number of tree height classes increased, the DF scores increased. But there is much overlap in a large range of DF1 scores among farms with organic and conventional practices (Figure 3). This figure shows that farms under transitional practices separate from organic and conventional farms by their lower DF1 scores. In both cases, these multivariate summary measures indicate that the organic farms were intermediate to the transitional and conventional farms. Originally, we expected that these phyto-geoclimate results from transitional farms would be intermediate between organic and conventional farms. This is somewhat puzzling and suggests there are possibly additional, unstudied, "lurking" variables contributing to the significant and positive relation between the AASM and PGSM among farms under organic cultivation practices,

\subsection{Factors Affecting Bird Species Richness, Abundance and Density}

Bird density estimation using methods that incorporate detection probability, such as the distance sampling method [37], is generally viewed with preference to relative abundance measurement only; albeit, results are dependent on meeting strict model assumptions, which are often hard to achieve. Also, by our not including birds detected more than $40 \mathrm{~m}$ in the direction of already surveyed plots behind us, our bird densities (per hectare) may be slightly lower.

However, our use of PCA produced a dimensionality reduced measure (AASM) of bird abundance per sampling plot that also yielded predictive information about bird density estimates from distance sampling calculations. Although this relationship has only moderate precision $\left(R^{2} \cong 0.50\right)$, it is nonetheless significantly positive. The slope of this relation was bird species, dependent as illustrated in Figure 4, and was markedly different between two groups of bird species, which groups corresponded to habitat generalists and specialists.

Among the five species with steep slopes for bird density vs. AASM, two are Nearctic-Neotropical migrant warblers, Yellow Warbler Setophaga petechia (SETPET) and Tennessee Warbler Oreothlypis peregrina (OREPER) wintering in Nicaragua. A third is a resident corvid, the White-throated Magpie Jay Calocitta formosa (CALFOR). All three species are well known habitat and resource generalists on their breeding grounds and, especially, throughout their wintering ranges (the two migrants) where they often occur from sea level to over 2000 m.a.s.l. (1250 m.a.s.l. for the jay) [53] [54] [55].

The two migratory species (SETPET, OREPER) had higher densities than any of the resident birds as expected because the study site lies within the Central Americas Flyway used by Nearctic-Neotropical migrants, many of whose numbers greatly increase during fall and spring passage through Nicaragua.

Note that the greater percentage of detections for SETPET and OREPER in conventional, rather than either organic or transitional plantations $(\sim 50 \%$ in 
conventional, $\sim 30 \%$ in organic, and $\sim 20 \%$ in transitional) was not consistent with our expectation. It is likely due to the concentration of "bird friendly" extrafloral nectaries and associated insects of the leguminous dominated overstory, e.g., Inga, Gliricidia and Erythrina spp., in conventional plantations [5] [8] [20] [31] [32] [33] [56] [57] [58].

The remaining two species of habitat generalists are hummingbirds: Steely-vented Hummingbird Amazilia saucerrottei (AMASAU) and Blue-throated Goldentail Hylocharis eliciae (HYLELI). Both are principally nectarivores that forage in diverse habitats ranging from open areas, e.g., agricultural lands and forest edge, to cloud and dry forests from sea level to 1200 m.a.s.l. [59] [60]. Not surprisingly, these species were in great abundance among sampling plots as well all sampling periods.

We believe it is unlikely that coffee cultivation practices would affect all birds in the same way. We found, in fact, no relation between AASM and PGSM for 5 habitat generalist species of the 21 species most frequently counted among farms. The same finding was also true for the remaining 16 habitat specialists among farms in transition or using conventional coffee cultivation practices. Only among farms using organic cultivation practices, was bird abundance/density (AASM) significantly and positively related to PGSM among habitat specialists.

The ANCOVA results substantiate our hypothesis that SETPET, OREPER, CALFOR, AMASAU and HYLELI are generalists that do not necessarily discriminate among habitats, and also explain the lack of statistical evidence of a relationship between PGSM and AASM. However, among the remaining 16 species wherein no migrants were represented, these behaved as habitat specialists in organic shade-coffee plantations, meaning that there was substantial value in PGSM as a predictor AASM and a positive correlation between them. This may be interpreted ecologically much like MacArthur and MacArthurs' [41] and Morton et al.'s [61] findings identifying, respectively, foliage height density and stem orientation as measures of habitat structure. Birds in these cases, i.e., those that visually discriminate the structure of the vegetation may perceive a greater potential as refugia from predation and the possibility of greater niche partitioning of 3-dimensional spatial resources including foraging strata and favorable sites for nesting within a given physical location of the forest and within particular vegetation types.

\section{Conclusion}

\section{Benefits of Organic Farms and Other "Biodiversity-Friendly" Coffee Sys-} tems

Our study demonstrates that bird abundance and density per hectare are higher within farms using organic shade-coffee cultivation practices. We assert that this is due to their incorporation of more mature (e.g., taller, structurally complex) tropical forest ecosystems, especially among habitat specialists. Our results confirm that shaded organic coffee plantations, which are most similar to 
surrounding forests in respect to overstory tree diversity and configuration, have more trophic structure and therefore support a greater variety of habitat specialists. Agricultural profit among the farm management types was not part of the present study. However, our results further substantiate that there is greater merit in organic farming over other coffee cultivation practices in preserving greater bird species richness, abundance and density. Increased crop revenue would be expected from reduced plant pest damage, owing to increased bird species richness and dietary/strata guild abundance and density. This applies especially to species that rely on particular habitat features that parallel those of the tropical forest ecosystem with its diverse and complex forest canopy and shrubby understory.

\section{Author Contributions}

All of the authors contributed to the conception and design of the study, acquisition of data, or analysis and interpretation of data. Martínez-Sánchez and Zolotoff assisted in summarizing coffee management strategies among the farms: organic and traditional polyculture shade coffee plantations. Zolotoff assisted Arendt (among others-see Acknowledgments below) in collecting the field data. Arendt wrote most of the ms. and conducted some of the traditional statistical analysis (parametric, non-parametric). Tuckfield, Thompson, and Reidy performed specialized statistical procedures (modelling, Distance Sampling, R, among others). Tuckfield derived the PGSM and AASM metrics, two novel ways to quantify vegetation parameters and avian species densities per unit area sections, wrote the related sections, and made numerous edits, adding wording and constructive comments throughout the manuscript's entirety. All authors provided editorial suggestions on various sections and drafts.

\section{Acknowledgements}

For assistance in the field and data collection, we thank Osmar Arróliga, Juana Isabel Matamoros, and Salvadora Morales. WJA thanks Judith D. Toms for insight into the intricacy of data correlations. Because this research formed part of a joint USAID/Nicaragua-USFS/IITF capacity building course offered to young biologists, we also compared observer bias in density estimation among our newly trained graduates, who participated in the avian surveys, and who continue to work in avian and conservation related research and management endeavors. This research would not have been possible without funding from the U.S. Agency for International Development/Nicaragua, the US Forest Service/International Institute of Tropical Forestry, and the foresight of Jerry Bauer, joint Senior Natural Resources Advisor and Mission Environmental Officer (USAID/Nicaragua) during the years of this study and, currently, Biological Scientist (USFS/IITF's International Cooperation Program). Much of this material is also based upon work supported by the Department of Energy under Award Number DE-FC-09-075R22506 to the University of Georgia Research 
Foundation and RCT. Portions of this research were also conducted in cooperation with the University of Puerto Rico. The use of trade or firm names in this publication is for reader information and does not imply endorsement by the US Forest Service of any product or service.

\section{Conflicts of Interest}

The authors declare no conflicts of interest regarding the publication of this paper.

\section{References}

[1] Wunderle, J.M. and Waide, R.B. (1993) Distribution of Overwintering Nearctic Migrants in the Bahamas and Greater Antilles. The Condor, 95, 904-933. https://doi.org/10.2307/1369428

[2] Perfecto, I., Rice, R.A., Greenberg, R. and Van der Voort, M.E. (1996) Shade Coffee: A Disappearing Refuge for Biodiversity. BioScience, 46, 598-608. https://doi.org/10.2307/1312989

[3] Wunderle, J.M. and Latta, S.C. (1994) Population Biology and Turnover of Nearctic Migrants Wintering in Small Coffee Plantations in the Dominican Republic. Journal für Ornithologie, 135, 477.

[4] Wunderle, J.M. and Latta, S.C. (1996) Avian Abundance in Sun and Shade Coffee Plantations and Remnants Pine Forests in the Cordillera Central, Dominican Republic. Ornitología Neotropical, 7, 19-34.

[5] Greenberg, R., Bichier, P. and Sterling, J. (1997) Bird Populations in Rustic and Planted Shade Coffee Plantations of Eastern Chiapas, México. Biotropica, 29, 501-514. https://doi.org/10.1111/j.1744-7429.1997.tb00044.x

[6] Wunderle, J.M. (1997) Commentary: Biodiversity in Shade Coffee Plantations. In: Rice, R.A., Harris, A. and McLean, J., Eds., Proceedings of the First Sustainable Coffee Congress, Smithsonian Migratory Bird Center, Washington DC, 183-185.

[7] Wunderle, J.M. (1999) Avian Distribution in Dominican Shade Coffee Plantations: Area and Habitat Relationships. Journal of Field Ornithology, 70, 58-70.

[8] Calvo, L. and Blakecentre, J. (1998) Bird Diversity and Abundance on Two Different Shade Coffee Plantations in Guatemala. Bird Conservation International, 8, 297-308. https://doi.org/10.1017/S0959270900001945

[9] Jones, J., Ramoni-Perazzi, P., Carruthers, E.H. and Robertson, R.J. (2002) Species Composition of Bird Communities in Shade Coffee Plantations in the Venezuelan Andes. Ornitología Neotropical, 13, 397-412.

[10] Philpott, S.M., Arendt, W.J., Armbrecht, I., Bichier, P. and Diestch, T. (2008) A Quantitative Review of Biodiversity Loss in Latin American Coffee Landscapes: Ants, Birds, and Trees. Conservation Biology, 22, 1093-1105. https://doi.org/10.1111/j.1523-1739.2008.01029.x

[11] Bakermans, M.H., Vitz, A.C., Rodewald, A.D. and Rengifo, C.G. (2009) Migratory Songbird Use of Shade Coffee in the Venezuelan Andes with Implications for the Conservation of the Cerulean Warbler. Biological Conservation, 142, 2476-2483. https://doi.org/10.1016/j.biocon.2009.05.018

[12] Komar, O. (2006) Ecology and Conservation of Birds in Coffee Plantations: A Critical Review. Bird Conservation International, 16, 1-23. 
https://doi.org/10.1017/S0959270906000074

[13] Greenberg, R., Bichier, P., Cruz Angon, A. and Reitsma, R. (1997) Bird Populations in Shade and Sun Coffee Pantations in Central Guatemala. Conservation Biology, 11, 448-459. https://doi.org/10.1046/j.1523-1739.1997.95464.x

[14] Marzluff, J.M. and Ewing, K. (2001) Restoration of Fragmented Landscapes for the Conservation of Birds: A General Framework and Specific Recommendations for Urbanizing Landscapes. Restoration Ecology, 9, 280-292. https://doi.org/10.1046/j.1526-100x.2001.009003280.x

[15] Carlo, T.A., Collazo, J.A. and Groom, M.J. (2004) Influences of Fruit Diversity and Abundance on Bird Use of Two Shaded Coffee Plantations. Biotropica, 36, 602-614. https://doi.org/10.1111/j.1744-7429.2004.tb00354.x

[16] Gleffe, J.D., Collazo, J.A., Groom, M.J. and Miranda-Castro, L. (2006) Avian Reproduction and the Value of Shaded Coffee Plantations. Ornitología Neotropical, 17, 271-282.

[17] Rice, R. (2010) The Ecological Benefits of Shadegrown Coffee: The Case for Going Bird Friendly. Smithsonian Migratory Bird Center, Washington DC, 1-8.

[18] Şekercioğlu, Ç. (2012) Birds Do Better in “Agroforests” than on Farms. Science Daily, 7 August 2012. https://www.sciencedaily.com/releases/2012/08/120807101357.htm

[19] Reitsma, R., Parrish, J.D. and McLarney, W. (2001) The Role of Cacao Plantations in Maintaining Forest Avian Diversity in Southeastern Costa Rica. Agroforestry Systems, 53, 185-193. https://doi.org/10.1023/A:1013328621106

[20] Milder, J.C., DeClerck, F.A.J., Sanfiorenzo, A., Merlo Sánchez, D. and Tobar, D.E. (2010) Effects of Farm and Landscape Management on Bird and Butterfly Conservation in Western Honduras. Ecosphere, 1, 1-22.

https://doi.org/10.1890/ES10-00003.1

[21] Greenberg, R., Bichier, P. and Angón, A.C. (2000) The Conservation Value for Birds of Cacao Plantations with Diverse Shade in Tabasco, Mexico. Animal Conservation, 3, 105-112. https://doi.org/10.1111/j.1469-1795.2000.tb00235.x

[22] Matlock Jr., E.B., Rogers, D., Edwards, P.J. and Martin, S.G. (2002) Avian Communities in Forest Fragments and Reforestation Areas Associated with Banana Plantations in Costa Rica. Agriculture, Ecosystems and Environment, 91, 199-215. https://doi.org/10.1016/S0167-8809(01)00232-8

[23] Luck, G.W. and Daily, G.C. (2003) Tropical Countryside Bird Assemblages: Richness, Composition, and Foraging Differ by Landscape Context. Ecological Applications, 13, 235-247. https://doi.org/10.1890/1051-0761(2003)013[0235:TCBARC]2.0.CO;2

[24] Pérez, A.M., Poveda, C., Siria, I., Aburto, L. and Sotelo, M. (2007) Developing a Species Based Model for Biodiversity Assessment in the Nicaraguan Pacific Slope. Technical Report. Asociación Gaia and the Netherlands Environmental Assessment Agency (MNP-SNV), Managua.

[25] Van Bael, S.A., Bichier, P., Ochoa, I. and Greenberg, R. (2007) Bird Diversity in Cacao Farms and Forest Fragments of Western Panama. Biodiversity and Conservation, 16, 2245-2256. https://doi.org/10.1007/s10531-007-9193-3

[26] Arendt, W.J., Tórrez, M. and Vílchez, S. (2012) Diversidad de Aves en Agropaisajes Cafetaleros en la Región Norte de Nicaragua. Ornitología Neotropical, 23, 113-131.

[27] Tórrez, M. and Arendt, W.J. (2013) Composición de Aves del Pacífico Sur de Nicaragua Enfatizando las Especies Indicadoras Dependientes de Bosque. Mesoamericana, 17, 39-48. 
[28] Estrada, A., Cammarano, P. and Coates-Estrada, R. (2000) Bird Species Richness in Vegetation Fences and in Strips of Residual Rain Forest Vegetation at Los Tuxtlas, Mexico. Biodiversity and Conservation, 9, 1399-1416. https://doi.org/10.1023/A:1008935016046

[29] Wunderle, J.M. and Latta, S.C. (2000) Winter Site Fidelity of Nearctic Migrant Birds in Isolated Shade Coffee Plantations of Different Sizes in the Dominican Republic. The Auk, 117, 596-614. https://doi.org/10.1093/auk/117.3.596

[30] Daily, G.C., Ehrlich, P.R. and Sánchez-Azofeifa, G.A. (2001) Countryside Biogeography: Use of Human-Dominated Habitats by the Avifauna of Southern Costa Rica. Ecological Applications, 11, 1-13. https://doi.org/10.1890/1051-0761(2001)011[0001:CBUOHD]2.0.CO;2

[31] Perfecto, I., Mas, A., Dietsch, T. and Vandermeer, J.H. (2003) Conservation of Biodiversity in Coffee Agroecosystems: A Tri-Taxa Comparison in Southern Mexico. Biodiversity and Conservation, 12, 1239-1252. https://doi.org/10.1023/A:1023039921916

[32] Petit, L.J. and Petit, D.R. (2003) Evaluating the Importance of Human-Modified Lands for Neotropical Bird Conservation. Conservation Biology, 17, 687-694. https://doi.org/10.1046/j.1523-1739.2003.00124.x

[33] Tejeda-Cruz, C. and Sutherland, W.J. (2004) Bird Responses to Shade Coffee Production. Animal Conservation, 7, 169-179. https://doi.org/10.1017/S1367943004001258

[34] Marsden, S.J. and Whiffin, M. (2003) The Relationship between Population Density, Habitat Position and Habitat Breadth within a Neotropical Forest Bird Community. Ecography, 26, 385-392. https://doi.org/10.1034/j.1600-0587.2003.03465.x

[35] Martínez-Sánchez, J.C. (2008) The Role of Organic Production in Biodiversity Conservation in Shade Coffee Plantations. PhD Thesis, University of Washington, Seattle.

[36] Thomas, L., Buckland, S.T., Rexstad, E.A., Laake, J.L., Strindberg, S., Hedley, S.L., Bishop, J.R.B., Marques, T.A. and Burnham, K.P. (2010) Distance Software: Design and Analysis of Distance Sampling Surveys for Estimating Population Size. Journal of Applied Ecology, 47, 5-14. https://doi.org/10.1111/j.1365-2664.2009.01737.x

[37] Buckland, S.T., Anderson, D.R., Burnham, K.P. and Laake, J.L. (2001) Introduction to Distance Sampling: Estimating Abundance of Biological Populations. Oxford University Press, Oxford.

[38] Neter, J., Kutner, M.H., Nachtsheim, C.J. and Wasserman, W. (1996) Applied Linear Statistical Models. McGraw-Hill, Boston.

[39] Rencher, A.C. (1998) Multivariate Statistical Inference and Applications, Volume 2, Methods of Multivariate Analysis. John Wiley \& Sons, New York.

[40] Jolliffe, I.T. (2002) Principal Component Analysis. 2nd Edition, Springer-Verlag, New York.

[41] MacArthur, R.H. and MacArthur, J.W. (1961) On Bird Species Diversity. Ecology, 42, 594-598. https://doi.org/10.2307/1932254

[42] McLachlan, G.J. (2004) Discriminant and Statistical Pattern Recognition. John Wiley \& Sons, Inc., Hoboken.

[43] Colwell, R.K., Chao, A., Gotelli, N.J., Lin, S. and Mao, C.X. (2012) Models and Estimators Linking Individual-Based and Sample-Based Rarefaction, Extrapolation and Comparison of Assemblages. Journal of Plant Ecology, 5, 3-21. https://doi.org/10.1093/jpe/rtr044 
[44] Pielou, E.C. (1975) Ecological Diversity. John Wiley \& Sons, New York.

[45] Leng, L., Zhang, T., Kleinman, L. and Zhu, W. (2007) Ordinary Least Square Regression, Orthogonal Regression, Geometric Mean Regression and the Applications in Aerosol Science. Journal of Physics, Conference Series, 78, Article ID: 012084. https://doi.org/10.1088/1742-6596/78/1/012084 http://iopscience.iop.org/17426596/78/1/012084/pdf/jpconf7_78_012084.pdf

[46] JMP. 1989-2007JMP ${ }^{\circledast}$, Version 9. SAS Institute Inc., Campus Drive, Cary, NC 27513.

[47] Tórrez, M., Arendt, W.J., Sotelo, M. and López, S.J.A. (2014) Indicadores Taxonómicos de Cambio de Hábitat en los Bosques Nubosos de Nicaragua. Universidad Centroamericana. Memoria del VIII Congreso Interdisciplinario de Investigación Universidad Centroamericana, Managua, 37-45.

[48] Schulze, C.H., Walter, M., Kessler, P.J.A., Pitopang, R. and Shadbuddin, D. (2004) Biodiversity Indicator Groups of Tropical Land-Use Systems, Comparing Plants, Birds and Insects. Ecological Applications, 14, 1321-1333. https://doi.org/10.1890/02-5409

[49] Hernández, S.M., Mattsson, B.J., Peters, V.E., Cooper, R.J. and Carroll, C.R. (2013) Coffee Agroforests Remain Beneficial for Neotropical Bird Community Conservation Across Seasons. PLoS ONE, 8, e65101. https://doi.org/10.1371/journal.pone.0065101

[50] Tórrez, M., Arendt, W.J. and Maes, J.M. (2013) Comunidades de Aves y Lepidópteros Diurnos y las Relaciones entre ellas en Bosque Nuboso y Cafetal de Finca Santa Maura, Jinotega. Encuentro, 95, 69-79. https://doi.org/10.5377/encuentro.v0i95.1225

[51] Freemark, K.E. and Kirk, D.A. (2001) Birds on Organic and Conventional Farms in Ontario: Partitioning Effects of Habitat and Practices on Species Composition and Abundance. Biological Conservation, 101, 337-350. https://doi.org/10.1016/S0006-3207(01)00079-9

[52] Leyequién, E., De Boer, W.F. and Toledo, V.M. (2010) Bird Community Composition in a Shaded Coffee Agro-Ecological Matrix in Puebla, Mexico: The Effects of Landscape Heterogeneity at Multiple Spatial Scales. Biotropica, 42, 236-245. https://doi.org/10.1111/j.1744-7429.2009.00553.x

[53] Rimmer, C.C. and Mcfarland, K.P. (1998) Tennessee Warbler (Oreothlypis Peregrina). The Birds of North America, Number 350. https://doi.org/10.2173/bna.350

[54] Lowther, P.E., Celada, C., Klein, N.K., Rimmer, C.C. and Spector, D.A. (1999) Yellow Warbler (Dendroica Petechia). The Birds of North America, Number 454. https://doi.org/10.2173/bna.454

[55] Marzluff, J. (2009) Family Corvidae (Crows). In: del Hoyo, J., Elliott, A. and Christie, D., Eds., Handbook of the Birds of the World, Volume 14, Bush-Shrikes to Old World Sparrows, Lynx Edicions, Barcelona, 587.

[56] Vannini, J.P. (1994) Nearctic Avian Migrants in Coffee Plantations and Forest Fragments of South-Western Guatemala. Bird Conservation International, 4, 209-232. https://doi.org/10.1017/S0959270900002781

[57] Moguel, P. and Toledo, V.M. (1999) Biodiversity Conservation in Traditional Coffee Systems of Mexico. Conservation Biology, 13, 11-21. https://doi.org/10.1046/j.1523-1739.1999.97153.x

[58] Smithsonian Migratory Bird Center (2008) Shade Management Criteria for Bird Friendly Coffee. National Zoological Park, Washington DC.

[59] Martínez-Sánchez, J.C., Chavarría-Duriaux, L. and Muñoz, F.J. (2014) A Guide to 
the Birds of Nicaragua-Una Guía de Aves. VerlagsKG Wolf, Mageburg.

[60] Martínez-Sánchez, J.C. and Will, T. (2010) Thomas R. Howell's Checklist of the Birds of Nicaragua as of 1993. Ornithological Monographs No. 68.

https://doi.org/10.1525/om.2010.68.1.1

[61] Morton, E.S., Van der Voort, M. and Greenberg, R.S. (1993) How a Warbler Chooses Its Habitat: Field Support for Laboratory Experiments. Animal Behaviour, 46, 47-53. https://doi.org/10.1006/anbe.1993.1160 


\section{Appendix}

Table A1. Species codes, scientific and common name, residency status ( $R=$ resident; $M=$ migrant), foraging guild $(C=$ carnivore; $\mathrm{F}$ = frugivore; $\mathrm{G}$ = granivore; $\mathrm{I}=$ insectivore; $\mathrm{N}$ = nectarivore; $\mathrm{O}=$ omnivore; $\mathrm{S}=$ scavenger $)$ and strata $(\mathrm{O}=$ overstory; $\mathrm{G}=$ ground; $\mathrm{S}=$ shrub; $\mathrm{T}$ = trunk; $\mathrm{U}=$ understory), number of observations (total number of points at which a species was detected), and total detections (total detections of individuals of a species) and detections by period and overstory and coffee at 200 count points visited four times inshade coffee plantations on Mambacho Volcano, Nicaragua, 1998-1999. Seasons correspond to the boreal seasons including winter (25 February - 1 March 1998), spring (16 March - 14 April 1999), summer (22 July - 5 August 1998), and fall (10 November - 21 November 1998). Symbol * after the species code refers to 16 species of habitat discrminators (small slope species) and symbol $\wedge$ refers to the five habitat generalist species (large slope species) as explained in text.

\begin{tabular}{|c|c|c|c|c|c|c|c|c|c|c|c|c|c|c|c|}
\hline \multirow{3}{*}{$\begin{array}{l}\text { Species } \\
\text { Code } \\
\text { AMAALB* }^{*}\end{array}$} & \multirow{3}{*}{$\begin{array}{l}\text { Scientific } \\
\text { Name } \\
\text { Amazona }\end{array}$} & \multirow[b]{2}{*}{$\begin{array}{l}\text { Common } \\
\text { Name }\end{array}$} & \multirow[b]{2}{*}{ Status } & \multirow[b]{2}{*}{ Guild } & \multirow[b]{2}{*}{ Strata } & \multirow[b]{2}{*}{$\begin{array}{l}\text { Number of } \\
\text { Observation }\end{array}$} & \multirow[b]{2}{*}{$\begin{array}{l}\text { Number of } \\
\text { Detections }\end{array}$} & \multicolumn{2}{|c|}{$\begin{array}{l}\text { Winter } \\
\text { (25 Feb. - } 1 \\
\text { Mar. 1998) }\end{array}$} & \multicolumn{2}{|c|}{$\begin{array}{l}\text { Summer } \\
\text { (22 Jul. - } 5 \\
\text { Aug. 1998) }\end{array}$} & \multicolumn{2}{|l|}{$\begin{array}{l}\text { Fall } \\
(10-21 \\
\text { Nov. 1998) }\end{array}$} & \multicolumn{2}{|c|}{$\begin{array}{l}\text { Spring } \\
\text { (16 Mar. - } 14 \\
\text { Apr. 1999) }\end{array}$} \\
\hline & & & & & & & & $\begin{array}{l}\text { Over- } \\
\text { story }\end{array}$ & Coffee & Overstory & Coffee & Overstory & Coffee & Overstory & Coffee \\
\hline & & $\begin{array}{l}\text { White-fronted } \\
\text { Parrot }\end{array}$ & $\mathrm{R}$ & f & o & 30 & 77 & 34 & 1 & 5 & 0 & 16 & 0 & 21 & 0 \\
\hline AMAAUR & $\begin{array}{l}\text { Amazona } \\
\text { auropalliata }\end{array}$ & $\begin{array}{l}\text { Yellow-naped } \\
\text { Parrot }\end{array}$ & $\mathrm{R}$ & $\mathrm{f}$ & o & 26 & 85 & 23 & 0 & 22 & 0 & 33 & 0 & 7 & 0 \\
\hline AMAFAR & $\begin{array}{l}\text { Amazona } \\
\text { farinosa }\end{array}$ & Mealy Parrot & $\mathrm{R}$ & $\mathrm{f}$ & o & 1 & 1 & 0 & 0 & 0 & 0 & 0 & 0 & 1 & 0 \\
\hline AMARUT $^{*}$ & $\begin{array}{l}\text { Amazilia } \\
\text { rutila }\end{array}$ & $\begin{array}{l}\text { Cinnamon } \\
\text { Hummingbird }\end{array}$ & $\mathrm{R}$ & $\mathrm{n}$ & $\mathrm{o}, \mathrm{s}$ & 30 & 32 & 8 & 1 & 7 & 1 & 4 & 2 & 9 & 0 \\
\hline AMASAU & $\begin{array}{l}\text { Amazilia } \\
\text { saucerrottei }\end{array}$ & $\begin{array}{l}\text { Steely-vented } \\
\text { Hummingbird }\end{array}$ & $\mathrm{R}$ & $\mathrm{n}$ & $0, \mathrm{~s}$ & 42 & 52 & 10 & 2 & 4 & 0 & 3 & 0 & 32 & 1 \\
\hline Amazona sp. & Amazona sp. & parrot sp. & & & & 23 & 55 & & & & & & & & \\
\hline ARANAN & $\begin{array}{l}\text { Eupsittula } \\
\text { (Aratinga) } \\
\text { nana }\end{array}$ & $\begin{array}{l}\text { Olive-throated } \\
\text { Parakeet }\end{array}$ & $\mathrm{R}$ & $\mathrm{f}$ & o & 6 & 54 & 35 & 0 & 19 & 0 & 0 & 0 & 0 & 0 \\
\hline Aratinga sp. & Eupsittula sp. & parakeet sp. & & & & 24 & 75 & & & & & & & & \\
\hline ARCCOL & $\begin{array}{l}\text { Archilochus } \\
\text { colubris }\end{array}$ & $\begin{array}{l}\text { Ruby-throated } \\
\text { Hummingbird }\end{array}$ & M & $\mathrm{n}$ & $\mathrm{o}, \mathrm{s}$ & 7 & 8 & 3 & 1 & 0 & 0 & 0 & 0 & 4 & 0 \\
\hline BROJUG & $\begin{array}{l}\text { Brotogeris } \\
\text { jugularis }\end{array}$ & $\begin{array}{l}\text { Orange-chinned } \\
\text { Parakeet }\end{array}$ & $\mathrm{R}$ & $\mathrm{f}$ & o & 25 & 106 & 3 & 0 & 57 & 0 & 36 & 0 & 10 & 0 \\
\hline BUTNIT & Buteo nitidus & Gray Hawk & $\mathrm{R}$ & c & o & 8 & 13 & 2 & 0 & 4 & 0 & 3 & 0 & 4 & 0 \\
\hline CALFOR & $\begin{array}{l}\text { Calocitta } \\
\text { formosa }\end{array}$ & $\begin{array}{l}\text { White-throated } \\
\text { Magpie-Jay }\end{array}$ & $\mathrm{R}$ & o & $\mathrm{o}, \mathrm{s}, \mathrm{u}$ & 400 & 402 & 155 & 5 & 104 & 0 & 52 & 0 & 86 & 0 \\
\hline CAMGUA & $\begin{array}{l}\text { Campephilus } \\
\text { guatemalensis }\end{array}$ & $\begin{array}{l}\text { Pale-billed } \\
\text { Woodpecker }\end{array}$ & $\mathrm{R}$ & $\mathrm{i}$ & $\mathrm{t}$ & 1 & 1 & 0 & 0 & 1 & 0 & 0 & 0 & 0 & 0 \\
\hline CHILIN* & $\begin{array}{l}\text { Chiroxiphia } \\
\text { linearis }\end{array}$ & $\begin{array}{l}\text { Long-tailed } \\
\text { Manakin }\end{array}$ & $\mathrm{R}$ & $\mathrm{f}$ & $\mathrm{o}, \mathrm{s}, \mathrm{u}$ & 199 & 361 & 111 & 20 & 115 & 34 & 30 & 0 & 51 & 0 \\
\hline CHLCAN & $\begin{array}{l}\text { Chlorostilbon } \\
\text { canivetii }\end{array}$ & $\begin{array}{l}\text { Canivet's } \\
\text { Emerald }\end{array}$ & $\mathrm{R}$ & $\mathrm{n}$ & $\mathrm{o}, \mathrm{s}$ & 16 & 19 & 9 & 8 & 0 & 0 & 0 & 0 & 2 & 0 \\
\hline Colibrisp. & Colibrisp. & $\begin{array}{l}\text { hummingbird } \\
\text { sp. }\end{array}$ & & & & 73 & 102 & & & & & & & & \\
\hline COLINC & Columbina inca & Inca Dove & $\mathrm{R}$ & $\mathrm{g}$ & g & 23 & 27 & 17 & 3 & 2 & 2 & 0 & 0 & 3 & 0 \\
\hline Columbina sp & Columbina sp. & dove sp. & & & & 4 & 4 & & & & & & & & \\
\hline CONALB & $\begin{array}{l}\text { Conopias } \\
\text { albovittatus }\end{array}$ & $\begin{array}{l}\text { White-ringed } \\
\text { Flycatcher }\end{array}$ & $\mathrm{R}$ & $\mathrm{i}$ & o & 1 & 1 & 0 & 0 & 0 & 0 & 0 & 0 & 1 & 0 \\
\hline CONSOR & $\begin{array}{l}\text { Contopus } \\
\text { sordidulus }\end{array}$ & $\begin{array}{l}\text { Western } \\
\text { Wood-Pewee }\end{array}$ & M & $\mathrm{i}$ & $\mathrm{o}, \mathrm{s}$ & 1 & 1 & 0 & 0 & 0 & 0 & 0 & 0 & 1 & 0 \\
\hline Contopus sp. & Contopus sp. & pewee sp. & & & & 11 & 11 & & & & & & & & \\
\hline CONVIR & $\begin{array}{l}\text { Contopus } \\
\text { virens }\end{array}$ & $\begin{array}{l}\text { Eastern } \\
\text { Wood-Pewee }\end{array}$ & M & $\mathrm{i}$ & $o, s$ & 17 & 17 & 2 & 0 & 0 & 0 & 11 & 0 & 4 & 0 \\
\hline CORATR & $\begin{array}{l}\text { Coragyps } \\
\text { atratus }\end{array}$ & Black Vulture & $\mathrm{R}$ & $\mathrm{s}$ & $o, g$ & 2 & 2 & 0 & 0 & 1 & 0 & 1 & 0 & 0 & 0 \\
\hline
\end{tabular}


Continued

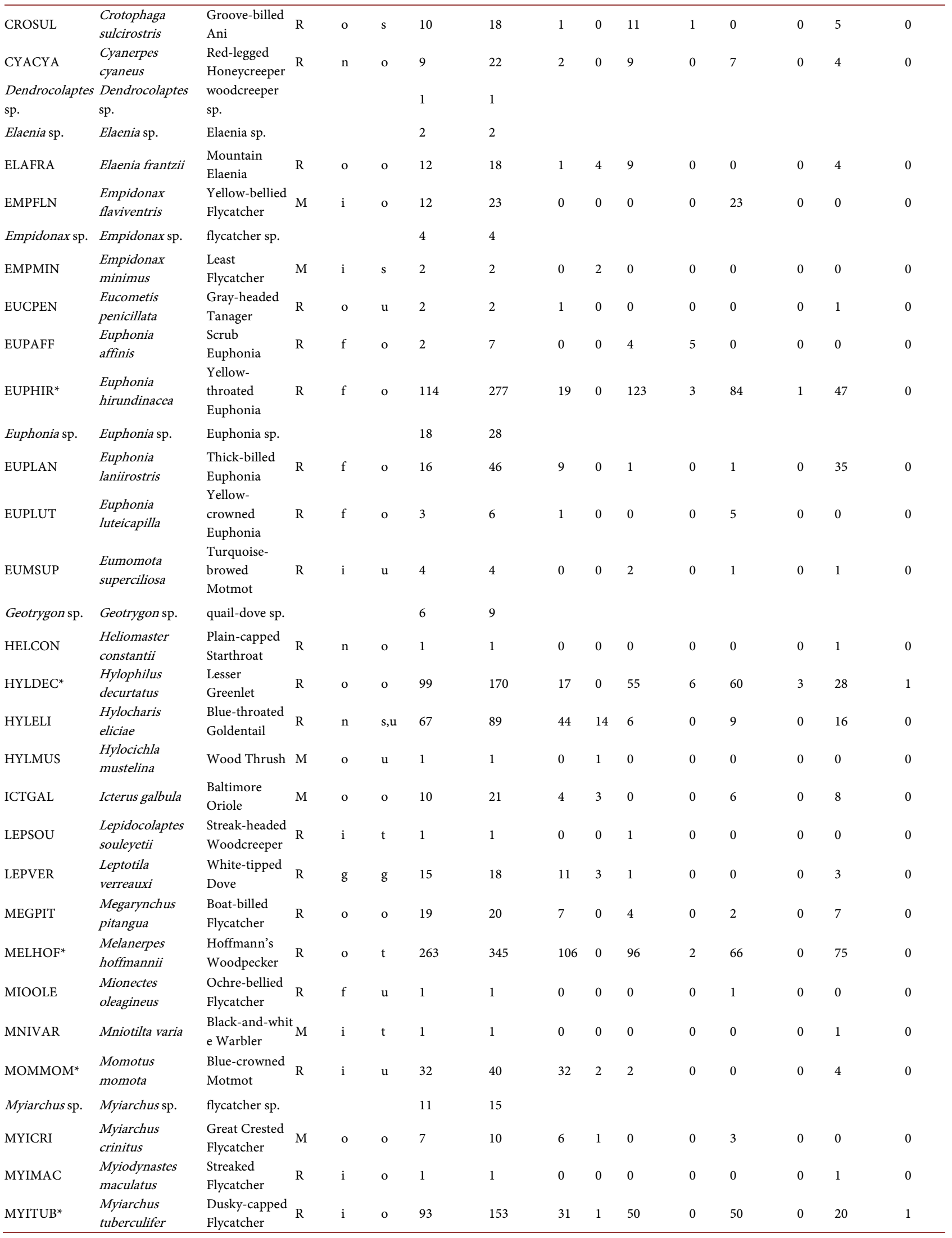




\section{Continued}

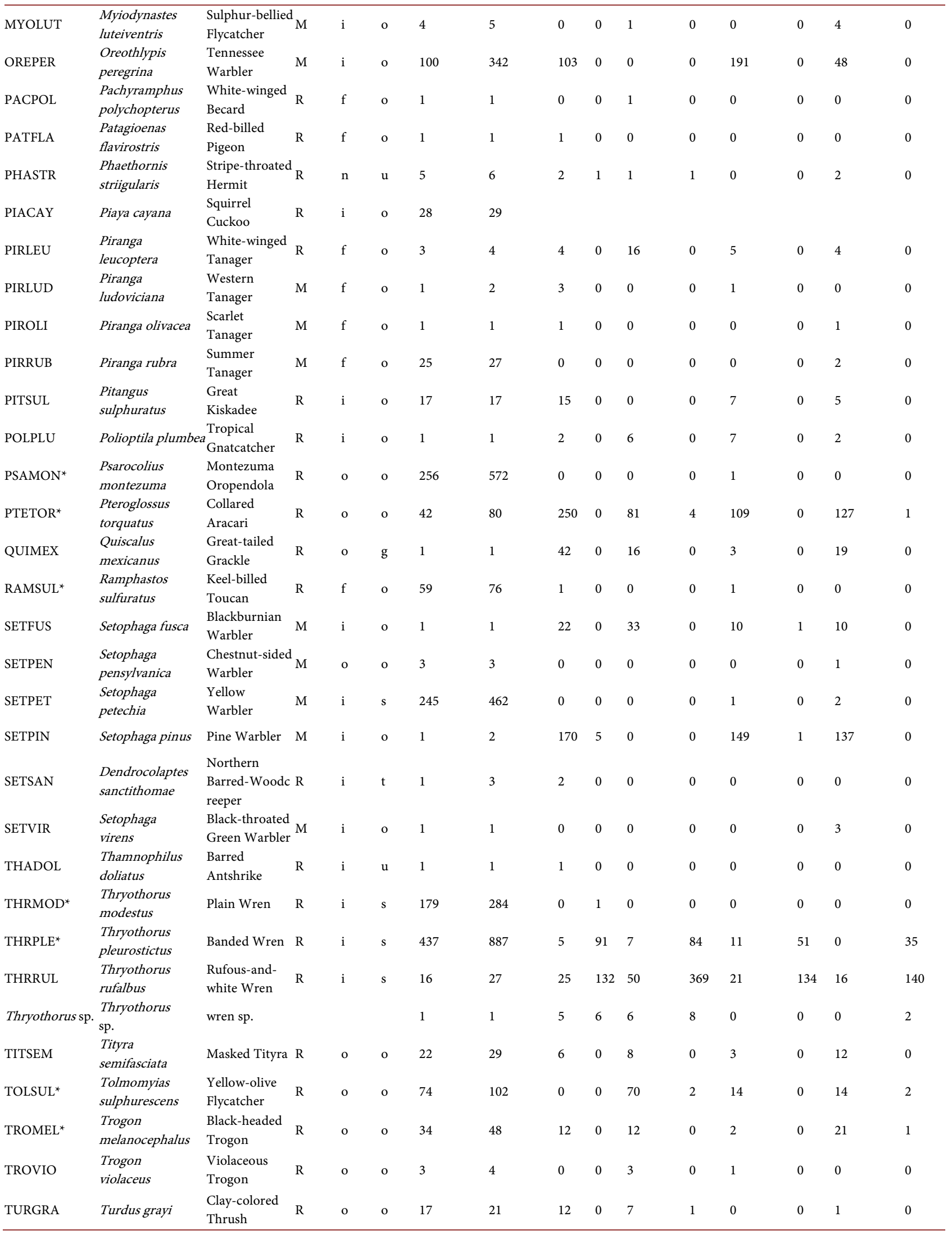




\section{Continued}

\begin{tabular}{|c|c|c|c|c|c|c|c|c|c|c|c|c|c|c|c|}
\hline TYRFOR & $\begin{array}{l}\text { Tyrannus } \\
\text { forficatus }\end{array}$ & $\begin{array}{l}\text { Scissor-tailed } \\
\text { Flycatcher }\end{array}$ & $\mathrm{M}$ & $\mathrm{i}$ & s & 5 & 5 & 2 & 0 & 0 & 0 & 0 & 0 & 3 & 0 \\
\hline VERCEL & $\begin{array}{l}\text { Vermivora } \\
\text { celata }\end{array}$ & $\begin{array}{l}\text { Orange-crowne } \\
\text { d Warbler }\end{array}$ & $\mathrm{e}_{\mathrm{M}}$ & o & o & 1 & 1 & 1 & 0 & 0 & 0 & 0 & 0 & 0 & 0 \\
\hline Vireo sp. & Vireo sp. & vireo $\mathrm{sp}$. & & & & 5 & 7 & & & & & & & & \\
\hline VIRFLD* & Vireo flavoviridis & $\begin{array}{l}\text { Yellow-green } \\
\text { Vireo }\end{array}$ & $\mathrm{R}$ & o & o & 37 & 77 & 2 & 0 & 24 & 1 & 39 & 0 & 11 & 0 \\
\hline VIRFLF & Vireo flavifrons & $\begin{array}{l}\text { Yellow- } \\
\text { throated Vireo }\end{array}$ & $\mathrm{M}$ & o & o & 3 & 3 & 0 & 0 & 0 & 0 & 3 & 0 & 0 & 0 \\
\hline VIROLI & Vireo olivaceus & Red-eyed Vireo & $\mathrm{M}$ & $\mathrm{o}$ & o & 2 & 4 & 0 & 0 & 0 & 0 & 2 & 0 & 2 & 0 \\
\hline VIRSOL & Vireo solitarius & $\begin{array}{l}\text { Blue-headed } \\
\text { Vireo }\end{array}$ & $\mathrm{M}$ & o & o & 1 & 3 & 0 & 0 & 0 & 0 & 1 & 0 & 2 & 0 \\
\hline VOLJAC & Volatinia jacarina & $\begin{array}{l}\text { Blue-black } \\
\text { Grassquit }\end{array}$ & $\mathrm{R}$ & $\mathrm{g}$ & g & 8 & 9 & 0 & 0 & 5 & 0 & 1 & 2 & 0 & 1 \\
\hline ZENASI & Zenaida asiatica & $\begin{array}{l}\text { White-winged } \\
\text { Dove }\end{array}$ & $\mathrm{R}$ & $\mathrm{g}$ & $\mathrm{g}$ & 9 & 11 & 4 & 0 & 7 & 0 & 0 & 0 & 0 & 0 \\
\hline
\end{tabular}

